Article

\title{
Effect of Manure and Urea Fertilization on Yield, Carbon Speciation and Greenhouse Gas Emissions from Vegetable Production Systems of Nigeria and Republic of Benin: A Phytotron Study
}

\author{
Abimfoluwa Olaleye ${ }^{1, *} \mathbb{B}$, Derek Peak ${ }^{1, *} \mathbb{B}$, Akeem Shorunke ${ }^{1}$, Gurbir Dhillon ${ }^{1}$, \\ Durodoluwa Oyedele ${ }^{2}$, Odunayo Adebooye ${ }^{3}$ and P.B. Irenikatche Akponikpe ${ }^{4}$ (D) \\ 1 Department of Soil Science, University of Saskatchewan, Saskatoon, SK S7N 5A8, Canada; \\ temitayo.shorunke@usask.ca (A.S.); g.dhillon@usask.ca (G.D.) \\ 2 Department of Soil Science and Land Resources Mgt., Obafemi Awolowo University, Ile-Ife 220005, Osun, \\ Nigeria; d_oyedele@yahoo.com \\ 3 Department of Crop Production and Protection, Obafemi Awolowo University, Ile-Ife 220005, Osun, Nigeria; \\ ocadebooye@daad-alumni.de \\ 4 Laboratory of Hydraulics and Environment Modeling, Department of Natural Resources Management, \\ Universite de Parakou, 03 BP: 351 Parakou, Republic of Benin; irenikatche.akponikpe@fa-up.bj \\ * Correspondence: oabimfoluwa@live.com (A.O.); derek.peak@usask.ca (D.P.)
}

Received: 14 February 2020; Accepted: 11 March 2020; Published: 14 March 2020

\begin{abstract}
Fertility management techniques being promoted in sub-Saharan Africa (SSA) seek to grow indigenous vegetables economically and sustainably. This study was conducted in a phytotron chamber and compared yield, soil carbon (C) speciation and greenhouse gas (nitrous oxide $\left(\mathrm{N}_{2} \mathrm{O}\right)$ and carbon dioxide $\left(\mathrm{CO}_{2}\right)$ ) emissions from SSA soils of two ecoregions; the dry savanna (lna, Republic of Benin) and rainforest (Ife, Nigeria) cultivated with local amaranth (Amaranthus cruentus) under manure ( $5 \mathrm{t} / \mathrm{ha}$ ) and/or urea ( $80 \mathrm{~kg} \mathrm{~N} / \mathrm{ha}$ ) fertilization. Vegetable yield ranged from $4331 \mathrm{~kg} / \mathrm{ha}$ to $7900 \mathrm{~kg} / \mathrm{ha}$ in the rainforest, $R F$, soils and $3165 \mathrm{~kg} / \mathrm{ha}$ to $4821 \mathrm{~kg} / \mathrm{ha}$ in the dry savanna, DS, soils. Yield in the urea treatment was slightly higher compared to the manure, and manure+urea treatment, but the difference was not statistically significant. Cumulative $\mathrm{CO}_{2}$ emissions over 21 days ranged from 497.06 to $579.47 \mathrm{~g} \mathrm{CO}_{2}-\mathrm{C} / \mathrm{kg}$ soil/day in the $R F$, and 322.96 to $624.97 \mathrm{~g} \mathrm{CO}_{2}-\mathrm{C} / \mathrm{kg}$ soil/day in the $D S$, while cumulative $\mathrm{N}_{2} \mathrm{O}$ emissions ranged from 60.53 to $220.86 \mathrm{mg} \mathrm{N}_{2} \mathrm{O}-\mathrm{N} / \mathrm{kg}$ soil/day in the $R F$, and 24.78 to $99.08 \mathrm{mg} \mathrm{N} \mathrm{N}_{2} \mathrm{O}-\mathrm{N} / \mathrm{kg}$ soil/day in the $D S$. In the $R F$ samples, when compared to the use of urea alone, the combined use of manure and urea reduced $\mathrm{N}_{2} \mathrm{O}$ emissions but led to an increase in the $D S$ samples. ATR-FTIR analysis showed that the combined use of manure and manure+urea increased the rate of microbial decomposition in the soils of the $D S$, but no such effect was observed in soils of the RF. We conclude that combining manure and urea fertilization has different effects on soils of the two ecoregions, and that $R F$ farmers can reduce agricultural $\mathrm{N}_{2} \mathrm{O}$ emissions without compromising soil productivity and yield potential.
\end{abstract}

Keywords: Sub-Saharan Africa; FTIR spectroscopy; fertilizer microdosing; African leafy vegetables; Greenhouse gas mitigation; sustainability; Tropical agriculture; soil fertility

\section{Introduction}

Agriculture is a major contributor to global anthropogenic greenhouse gas (GHG) emissions, primarily from the use of mineral fertilizers and manures to crop and soil systems, as well as cultivation of peatlands [1,2]. Africa currently contributes significantly to the global $\mathrm{N}_{2} \mathrm{O}$ emissions 
from agricultural soils [3] despite its current low average fertilizer application rates of $9 \mathrm{~kg} \mathrm{~N} \mathrm{ha}^{-1}$; which is very low compared to $135 \mathrm{~kg} \mathrm{~N} \mathrm{ha}^{-1}$ in Asia and $73 \mathrm{~kg} \mathrm{~N} \mathrm{ha}^{-1}$ in Latin America [4]. $\mathrm{N}$ fertilization is expected to increase in sub-Saharan Africa (SSA) by up to six-fold from the current levels in this century [5,6], since agricultural productivity in SSA is limited by low soil fertility [7]. Farmers in SSA are adopting the combined use of inorganic fertilizers and manures/crop residues to increase agricultural yields [8,9] as part of a widely accepted package of practices called Integrated Soil Fertility Management (ISFM); however little research has been performed on the environmental sustainability (including GHG emissions) of ISFM practices in African agricultural systems.

Increasing $\mathrm{N}$ fertilizer rates is known to increase soil $\mathrm{N}_{2} \mathrm{O}$ emission and contribute towards global warming [5]. The magnitude of soil $\mathrm{N}_{2} \mathrm{O}$ emissions is dependent on factors such as $\mathrm{N}$ fertilization rates, $\mathrm{N}$ fertilizer form [10], soil properties such as aeration, $\mathrm{C}$ bioavailability, and $\mathrm{N}$ utilization efficiency [11,12]. However, many studies [9,12-14] have reported that combining organic and inorganic fertilizers led to a reduction in soil $\mathrm{N}_{2} \mathrm{O}$ emissions and an increase in crop yields in Mali and Zimbabwe. These studies suggested that a combination of organic fertilization with low rates of inorganic $\mathrm{N}$ can be used as a mitigation option for reducing $\mathrm{N}_{2} \mathrm{O}$ emissions while retaining similar crop yields. Meanwhile, organic materials have also been shown to enhance the emissions of $\mathrm{N}_{2} \mathrm{O}$ and $\mathrm{CO}_{2}$ when in combination with urea fertilizers [15,16], primarily due to the production of $\mathrm{CO}_{2}$ by the hydrolysis of urea to $\mathrm{CO}_{2}$ and ammonia, as well as stimulation of heterotrophic microbial activity [17].

Changes in land management practices and cropping systems can significantly influence nutrient cycling and GHG emissions by altering soil chemical, physical and biological properties [11,18-20]. Dick et al. (2008) [13] reported that $4.1 \%$ of urea added to a pearl millet field in Mali was lost as $\mathrm{N}_{2} \mathrm{O}$ within the first year, while Singh and Verma (2007) [21] estimated that $70 \%$ of current $\mathrm{N}$ demand by plants is supplied by inorganic fertilizers, and as much as $50-70 \%$ of it is lost from nitrification processes leading to nitrate leaching and nitrous oxide emission.

Because organic matter is so tightly coupled to GHG emissions, advanced spectroscopic techniques, such as attenuated total reflectance Fourier transform infrared (ATR-FTIR) spectroscopy that can examine changes in the chemical forms of organic compounds [22] are vital to assessing soil organic carbon (SOC) quality in cropping systems. ATR-FTIR analysis of soils uses the vibrational characteristics of organic compounds to characterize the functional group chemistry of SOC $[23,24]$ and investigate the effect of agronomic management practices on the composition and dynamics of SOC at molecular scale in the soils [24-26]. Currently, we have little information on how $\mathrm{N}$ fertilization affects $\mathrm{C}$ speciation/transformation, and $\mathrm{N}_{2} \mathrm{O}$ and $\mathrm{CO}_{2}$ emissions in vegetable production systems of SSA. Therefore, understanding how $\mathrm{C}$ and $\mathrm{N}$ cycles under cultivation of indigenous vegetables on West African soils respond to the application of organic manure and fertilizer microdosing is crucial in estimating the sustainability and productivity of the soil.

Indigenous leaf vegetables such as the local amaranth (Amaranthus cruentus) are an integral part of agriculture in SSA; they contribute to human nutrition and traditional medicine and play a key role in the rural economy and family subsistence. The objective of this study is to investigate the effect of manure and fertilizer treatments on both GHG emissions and soil organic matter (SOM) speciation by determining and quantifying the impact of reduced mineral nitrogen fertilization and organic manure on vegetable yield, emission of $\mathrm{CO}_{2}$ and $\mathrm{N}_{2} \mathrm{O}$ from SSA soils cultivated with an indigenous vegetable in a controlled environment. We hypothesize that vegetable yield, $\mathrm{C}$ speciation and soil emissions of GHGs $\left(\mathrm{CO}_{2}\right.$ and $\left.\mathrm{N}_{2} \mathrm{O}\right)$ from vegetable production in SSA soils is affected by fertility management.

\section{Materials and Methods}

\subsection{Study Sites}

Soil sampling for this study was performed at two field sites - (a) Ina, Benin Republic $\left(9^{\circ} 95 \mathrm{~N}\right.$, $2^{\circ} 72 \mathrm{E}$ ) with an elevation of $380 \mathrm{~m}$, annual precipitation of $1073 \mathrm{~mm}$ and a mean temperature of $26.5^{\circ} \mathrm{C}$ and (b) Ife, Nigeria $\left(07^{\circ} 29^{\prime} 21.9^{\prime \prime} \mathrm{N} 004^{\circ} 34^{\prime} 17.3^{\prime \prime}\right.$ E) with an altitude of $293 \mathrm{~m}$, annual precipitation of 
$1317 \mathrm{~mm}$ and a mean temperature of $25.6^{\circ} \mathrm{C}$, was collected and used in this phytotron study. The field site at Ina is in the dry savanna (DS) ecoregion, while the site at Ife falls within the rainforest $(R F)$ ecoregion of Nigeria. The soils were classified as Haplic Lixisols (LXha) and Plethnic Plinthosols (PTpx), for the two eco-regions respectively [27]. Lixisols are slightly acidic soils dominated by kaolinite clays, while Plinithosols are rich in iron and manganese and have a mix of kaolinite, quartz and other minerals [27], both soil types are coarse textured. Representative soil samples were collected systematically from 10 spots on each field following a ' $\mathrm{W}$ ' pattern and at $20 \mathrm{~m}$ intervals between each spot from field sites in both ecoregions using a soil auger up to a depth of $20 \mathrm{~cm}$ and homogenized into one composite sample. Soils were air dried, collected in plastic bags and shipped to the University of Saskatchewan for the phytotron experiment.

The soils were randomly distributed into different pre-designed treatments soil pots $(0.15 \mathrm{~m}$ in diameter and height) in equal volumes, mixed with manure (for the treatments requiring manure), cultivated with the local amaranth (Amaranthus cruentus) grown from seed in the phytotron. The growth chambers were set for $16 \mathrm{~h}$ at $25^{\circ} \mathrm{C}$ (day) and $8 \mathrm{~h}$ at $18{ }^{\circ} \mathrm{C}$ (night), relative humidity was approximately $55( \pm 5) \%$. The experimental pots consisted of a control (C) treatment, manure (M) treatment, Manure $+80 \mathrm{~kg} \mathrm{~N} / \mathrm{ha}(\mathrm{M} 80)$ treatment, No manure $+80 \mathrm{~kg} \mathrm{~N} / \mathrm{ha}(\mathrm{O} 80)$ treatment and an empty soil pot microdosed (with $80 \mathrm{~kg} \mathrm{~N} / \mathrm{ha}$ ) without any vegetables (S80). $\mathrm{N}$ was applied as urea, and cattle manure was applied at $5 \mathrm{t} / \mathrm{ha}$, and it contained $4.5 \% \mathrm{C}, 0.33 \% \mathrm{~N}$, and $0.21 \% \mathrm{P}$ by weight. The experimental pots were arranged in a randomized complete block design and replicated 3 times for the two ecozones (i.e., $D S$ and $R F$ ).

Soil samples were collected before planting and after harvest, air-dried, sieved ( $>2 \mathrm{~mm})$, and analyzed for particle size, $\mathrm{pH}, \mathrm{EC}$, total N, total $\mathrm{P}$, total organic $\mathrm{C}$, and C FTIR using standard methods. The vegetables were grown for 45 days after emergence. Particle size analysis was done using the hydrometer method [28], $\mathrm{pH}$ was measured in triplicate using a glass electrode in a 2:1 water:soil suspension, with $10 \mathrm{~mL}$ of water and $5 \mathrm{~g}$ of soil [28]. The TOC was analyzed using triplicate $0.25 \mathrm{~g}$ of very fine ( $<250 \mu \mathrm{m}$ particle size) samples on an automated C632 LECO analyzer (LECO (C Corporation, 1987 ) with a preset combustion temperature of $1100{ }^{\circ} \mathrm{C}$. Low $\mathrm{C}$ standard reference materials was used for calibration and a quality control sample was measured after every 20 samples. Total $\mathrm{N}$ and $\mathrm{P}$ were measured in triplicate using the $\mathrm{H}_{2} \mathrm{SO}_{4}-\mathrm{H}_{2} \mathrm{O}_{2}$ acid block digestion method of Thomas et al. (1967). Digests were then allowed to cool to room temperature, diluted and analyzed on a Folio AA3 auto-analyzer. A standard soil of known concentration of $\mathrm{N}$ was used for quality control.

\subsection{Measurement of GHG Emissions}

The GHG experiment was conducted under controlled conditions in the phytotron. Gas samples were collected at $0,1,2,3,4,5,8,14$ and 21 days after planting from the experimental pots to determine total $\mathrm{N}_{2} \mathrm{O}$ and $\mathrm{CO}_{2}$ emissions. Air samples were collected from the headspace of the soil pot using a $30 \mathrm{~mL}$ gas-tight syringe at time 0 and then at $60 \mathrm{~min}$ (the chambers did not have fans to circulate the air, so we assumed that the air would equilibrate after $60 \mathrm{~min}$ ). The collected air samples were transferred to a pre-evacuated 12-mL Exetainer vial (Labco Inc.; Ceredigion, UK) that was then analyzed via gas chromatography to determine the total concentrations of $\mathrm{N}_{2} \mathrm{O}$ and $\mathrm{CO}_{2}$ in the headspace samples. Ambient air samples were collected, and the ambient air temperature inside the chambers was also recorded. Total concentrations of $\mathrm{N}_{2} \mathrm{O}$ and $\mathrm{CO}_{2}$ in the headspace gas were determined using a Scion 456-GC gas chromatograph equipped with an electron capture detector (ECD) for the determination of $\mathrm{N}_{2} \mathrm{O}$ and a thermal conductivity detector (TCD) for the determination of $\mathrm{CO}_{2}$. To avoid 'pulsing' or the 'Birch effect' [29], soil pots were watered to $50( \pm 4) \%$ water filled pore space at most $12 \mathrm{~h}$ before gas samples were taken. The $\mathrm{N}_{2} \mathrm{O}$ and $\mathrm{CO}_{2}$ emissions was calculated as the product of the increase in $\mathrm{N}_{2} \mathrm{O}$ and $\mathrm{CO}_{2}$ concentration above ambient air and the volume of the headspace divided by the time the headspace was sealed and the soil surface area. 


\subsection{FTIR Spectroscopy}

Speciation of SOC for the finely ground soil samples was investigated using ATR-FTIR spectroscopy using a Bruker Optics Equinox 55 FTIR spectrometer equipped with a Mercury Cadmium Teluride (MCT) detector and single bounce PlatinumIR ATR accessory with diamond coated ZnSe optics. Spectra were collected by averaging 128 scans at $4 \mathrm{~cm}^{-1}$ resolution over a spectral range of $4000-400 \mathrm{~cm}^{-1}$ and were background corrected by using the spectrum of the empty ATR crystal with ambient air as reference. The 1800-900 $\mathrm{cm}^{-1}$ region was considered for the analysis of $C$ functional groups in this study; the spectral region between 900 to $400 \mathrm{~cm}^{-1}$ was excluded due to being dominated by vibrations of soil minerals [30], while the bands between 2700 and $1800 \mathrm{~cm}^{-1}$ were excluded because the information attributable to organic matter is masked by C-C stretching of the diamond ATR crystal and noise from $\mathrm{CO}_{2}$. Similarly, the bands at about $3600-3000 \mathrm{~cm}^{-1}$ are strongly influenced by water content [31] and were excluded as they may vary between the analyzed soil samples. Baseline correction of the spectra was performed using OPUS (ver. 6.5, Bruker Optik GmbH, Ettlingen, Germany) spectral processing software package. As there is a strong overlap among the bands of organic functional groups, individual bands were resolved by spectral deconvolution using a series of Gaussian curves fit on the Fityk software package (version 1.2.1) [32] as described in Dhillon et al. (2017) [24]. Spectral deconvolution was performed on a total of 39 samples from $R F$ and $D S$ ecoregions.

The curve parameters were constrained to ensure equal FWHM (full width at half maximum) of the curves. Individual spectral band identification was performed by using the available knowledge of characteristic infrared peak positions of soil organic compounds as reported in the literature, and the peaks were fitted as shown in Figure 1. Peaks were excluded from further analysis when not present in $\geq 5$ samples. The relative absorbance intensity ( $\mathrm{rA}$ ) of the deconvoluted bands was calculated by dividing the area of individual bands within the $1800-900 \mathrm{~cm}^{-1}$ wavenumber region (i.e., 1000, 1100, $1160,1430,1540,1600,1640 \mathrm{~cm}^{-1}$ ) with the sum of total area of all the bands in this region (e.g., $\mathrm{A}_{1540}=$

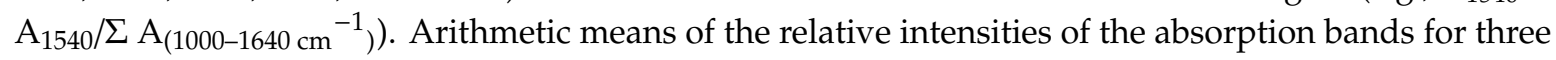
soil samples, collected from each soil pot, were calculated for each band to obtain the representative relative intensities of the bands for all samples. The relative intensity of the bands depends on the amount of absorbing functional groups, and it was used as a semi-quantitative estimate of the relative proportion of $C$ functional group within each soil sample, such that high absorption intensity indicates high content of the corresponding functional group and vice versa [33].

\subsection{Statistical Analysis}

IBM Statistical Package of Social Sciences (SPSS Inc.) statistics v.26 was used to perform repeated measure analysis of variance (ANOVA) to determine the significance of treatment and interaction effect on vegetable yield, soil chemical properties, and gas measurements. Tukey's Least-significant difference (LSD) test at a probability level of $p \leq 0.05$ was used for post-hoc comparison of individual treatments within the ecoregions. Pearson correlation was used to determine the relationship between spectral bands and soil chemical properties. 


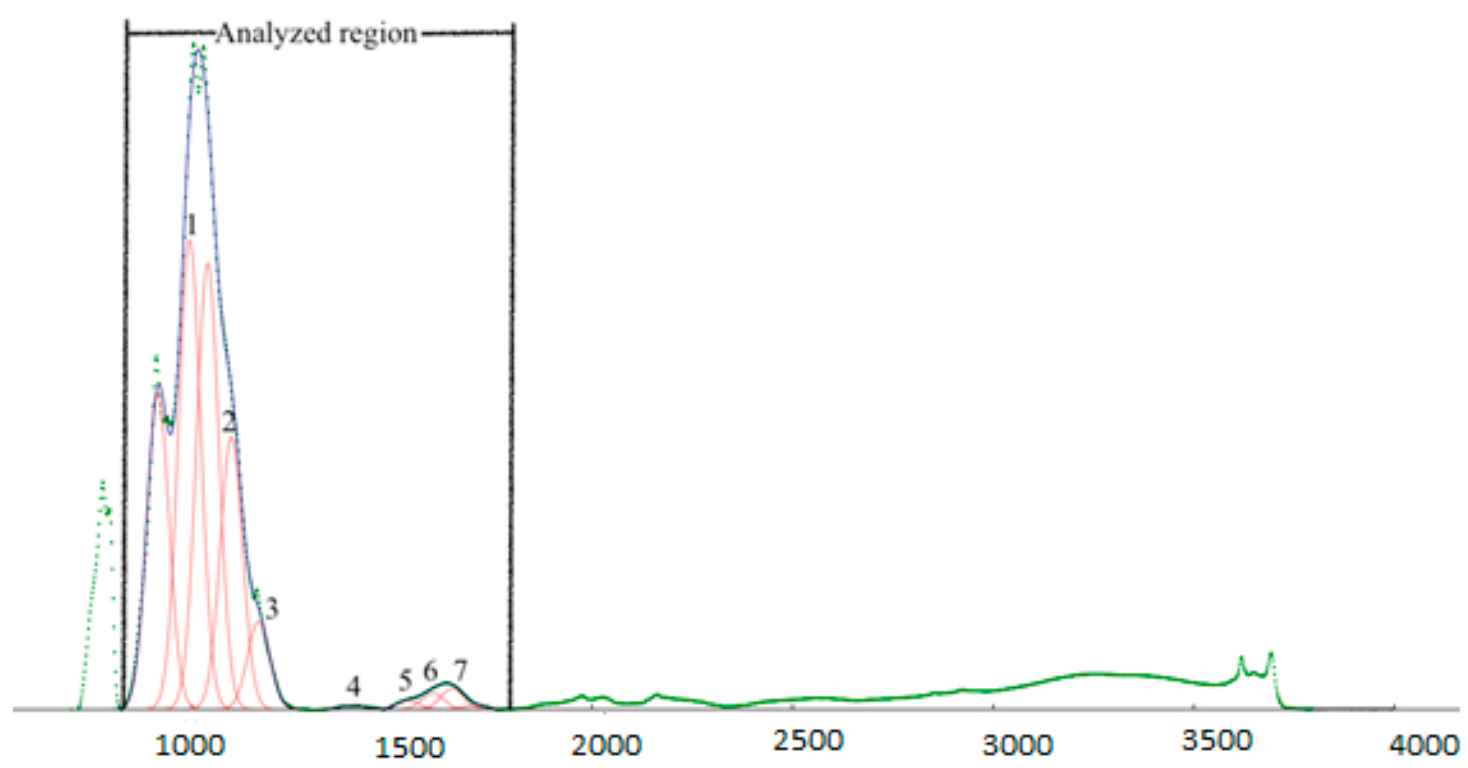

Figure 1. A representative ATR-FTIR spectra of whole soils showing the fitted Gaussian peaks representing the major $C$ functional groups within the wavenumber range of $900-1800 \mathrm{~cm}^{-1}$. Peaks are identified as follows: $1-1000 \mathrm{~cm}^{-1}, 2-1100 \mathrm{~cm}^{-1}, 3-1160 \mathrm{~cm}^{-1}, 4-1430 \mathrm{~cm}^{-1}, 5-1540 \mathrm{~cm}^{-1}$, $6-1600 \mathrm{~cm}^{-1}, 7-1640 \mathrm{~cm}^{-1}$.

\section{Results}

\subsection{Soil $\mathrm{pH}$ and Vegetable Yield}

Vegetable yield and soil $\mathrm{pH}$ for control and fertilizer treatments for the soil samples of both ecoregions are shown in Figure 2a,b respectively. $R F$ samples generally had a significantly lower $\mathrm{pH}$ except for O80 and $\mathrm{S} 80$ (Figure 2b; Tables 1 and 2), and significantly higher vegetable yield (Figure 2a) compared to the $D S$ samples. The $\mathrm{pH}$ ranged from 4.7 to 5.5 in the $R F$ soil samples and 4.5 to 6.1 in the $D S$ soil samples for different fertilizer treatments (Figure 2b). In soils of both ecoregions, soil pH was significantly affected by treatment (Table 2). In the RF samples, all treatments increased soil $\mathrm{pH}$ compared to the control, with the increment in $\mathrm{pH}$ highest in the urea treatment, O80 (Figure 2b). In the $D S$ samples, the $\mathrm{M}$ and $\mathrm{M} 80$ treatments significantly increased soil $\mathrm{pH}$, while the treatments which received urea only maintained (O80) or reduced (S80) soil pH compared to the control treatment (2b).

Soil $\mathrm{pH}$ was significantly reduced after harvest in the $D S$ samples for all treatments except S80, while in the $R F$ samples, the difference in soil $\mathrm{pH}$ after harvest was not statistically significant ( $p=0.243$ ). Yields ranged from $4330 \mathrm{~kg} / \mathrm{ha}$ to $7900 \mathrm{~kg} / \mathrm{ha}$ in the $R F$, and $3165 \mathrm{~kg} / \mathrm{ha}$ to $4821 \mathrm{~kg} / \mathrm{ha}$ in the DS (Figure 2a). Note that $\mathrm{S} 80$ has no yield because no vegetable was seeded into that treatment. While the yield difference between the RF and DS ecoregions was significant (Table 2), statistical analysis showed that all treatments that received some sort of $\mathrm{N}$ fertilization, either manure, urea or both, yielded significantly better than the control in both ecoregions (Figure 2a). In samples from both ecoregions, vegetable yield was highest in the treatment that received only urea, O80, followed by the treatment that received both urea and manure (M80), and the treatment that received only manure (M). However, the yield differences between the M, O80 and M80 treatments was not significant. 

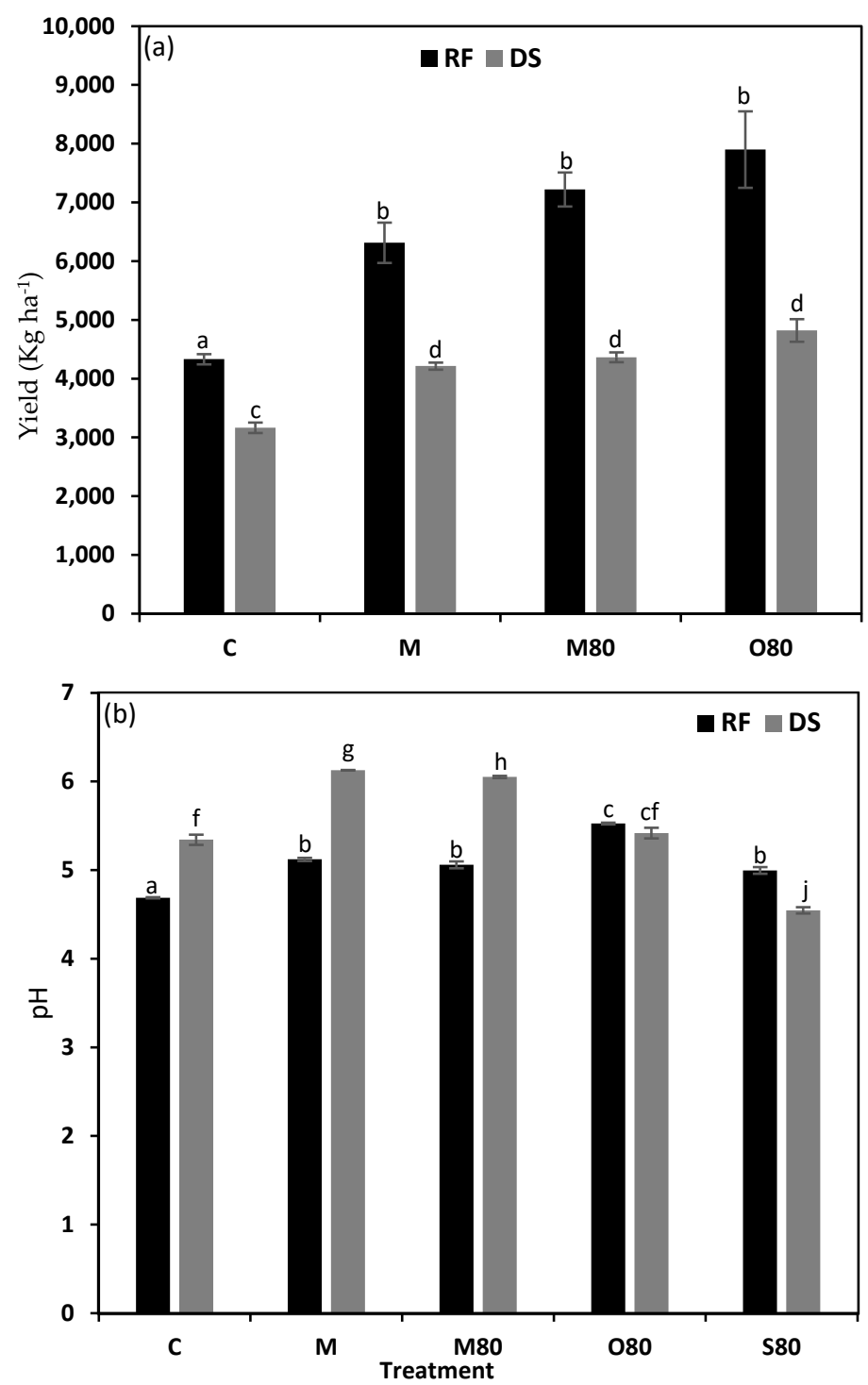

Figure 2. Treatment effect on (a) Yield and (b) soil pH of the Rainforest, RF, and Dry Savanna, DS, soils. $\mathrm{C}=$ control, $\mathrm{M}=$ manure treatment, $\mathrm{M} 80=$ Manure $+80 \mathrm{~kg} \mathrm{~N} / \mathrm{ha}, \mathrm{O} 80=$ No manure $+80 \mathrm{~kg} \mathrm{~N} / \mathrm{ha}$ $\mathrm{S} 80$ = soil pot microdosed with $80 \mathrm{~kg} \mathrm{~N} /$ ha without any vegetables. Bars with different letter(s) for each site are significantly different at $p<0.05 .(\mathrm{n}=3)$.

\subsection{Soil $N, P$ and organic $C$ content}

Total N concentrations ranged from 0.12 to $0.22 \%$ in the RF samples and 0.07 to $0.10 \%$ in the DS samples. Total P concentrations ranged from 0.06 to $0.08 \%$ in the $R F$ and 0.04 to $0.06 \%$ in the $D S$, while organic C concentrations ranged from 1.66 to $1.87 \%$ in the $R F$ and 0.55 to $0.63 \%$ in the $D S$ (Table 1 ). The difference in the total N, P and organic $\mathrm{C}$ concentrations between the ecoregions is statistically significant (Table 1). Within the ecoregions, statistical analysis found no significant treatment and time effect on total N, $\mathrm{P}$ and organic $\mathrm{C}$ concentrations, indicating that the addition of urea and/or manure does not significantly increase $\mathrm{N}, \mathrm{P}$, and organic $\mathrm{C}$ concentrations in this system and at the rates applied. However, in the DS samples, treatment effect on organic C concentrations was significant (Table 2), with the single addition of manure increasing the organic $C$ concentration, while the combined addition of manure+urea M80, maintained the current level of organic $C$ concentration (Table 1). The urea treatments, $\mathrm{O} 80$ and S80, saw a decline in organic C concentration (Table 1). 
Table 1. Carbon content, $\mathrm{pH}$, total phosphorus and total nitrogen concentrations of soil samples by ecoregion and treatment. Values are Mean (standard error). $(\mathrm{n}=3) . \mathrm{C}=$ control, $\mathrm{M}=$ manure treatment, $\mathrm{M} 80=$ Manure $+80 \mathrm{~kg} \mathrm{~N} / \mathrm{ha}, \mathrm{O} 80=$ No manure $+80 \mathrm{~kg} \mathrm{~N} / \mathrm{ha} \mathrm{S80}=$ soil pot microdosed with $80 \mathrm{~kg}$ $\mathrm{N} /$ ha without any vegetables. $\mathrm{BP}=$ Before planting, $\mathrm{AH}=$ After harvest.

\begin{tabular}{|c|c|c|c|c|c|c|c|c|}
\hline \multirow{2}{*}{ Treatment } & \multicolumn{2}{|c|}{$\mathrm{pH}$} & \multicolumn{2}{|c|}{ Total P (\%) } & \multicolumn{2}{|c|}{ Organic C (\%) } & \multicolumn{2}{|c|}{ Total N (\%) } \\
\hline & BP & $\mathbf{A H}$ & BP & $\mathbf{A H}$ & BP & $\mathbf{A H}$ & $\mathbf{B P}$ & $\mathbf{A H}$ \\
\hline \multicolumn{9}{|l|}{ Rainforest } \\
\hline C & $4.7(0.02)$ & $4.7(0.02)$ & $0.08(0.003)$ & $0.07(0.001)$ & $1.75(0.04)$ & $1.81(0.05)$ & $0.20(0.01)$ & $0.12(0.02)$ \\
\hline $\mathrm{M}$ & $5.2(0.02)$ & $5.0(0.02)$ & $0.07(0.002)$ & $0.07(0.002)$ & $1.70(0.01)$ & $1.80(0.08)$ & $0.21(0.02)$ & $0.20(0.03)$ \\
\hline M80 & $4.9(0.04)$ & $5.2(0.04)$ & $0.07(0.006)$ & $0.07(0.002)$ & $1.66(0.09)$ & $1.84(0.05)$ & $0.18(0.01)$ & $0.20(0.05)$ \\
\hline O80 & $5.9(0.06)$ & $5.2(0.05)$ & $0.07(0.002)$ & $0.06(0.002)$ & $1.87(0.02)$ & $1.84(0.02)$ & $0.22(0.03)$ & $0.22(0.02)$ \\
\hline $\mathrm{S} 80$ & $4.8(0.05)$ & $5.2(0.03)$ & $0.06(0.006)$ & $0.07(0.002)$ & $1.81(0.03)$ & $1.71(0.11)$ & $0.13(0.01)$ & $0.16(0.03)$ \\
\hline \multicolumn{9}{|l|}{ Dry Savanna } \\
\hline C & $5.5(0.06)$ & $5.2(0.05)$ & $0.04(0.001)$ & $0.04(0.002)$ & $0.56(0.01)$ & $0.58(0.02)$ & $0.08(0.01)$ & $0.08(0.01)$ \\
\hline $\mathrm{M}$ & $6.4(0.04)$ & $5.8(0.04)$ & $0.04(0.001)$ & $0.04(0.001)$ & $0.62(0.01)$ & $0.63(0.01)$ & $0.10(0.01)$ & $0.08(0.01)$ \\
\hline M80 & $6.3(0.007)$ & $5.8(0.02)$ & $0.04(0.001)$ & $0.04(0.001)$ & $0.56(0.01)$ & $0.56(0.01)$ & $0.09(0.01)$ & $0.10(0.02)$ \\
\hline O80 & $5.6(0.06)$ & $5.3(0.06)$ & $0.04(0.001)$ & $0.04(0.001)$ & $0.62(0.02)$ & $0.60(0.02)$ & $0.08(0.01)$ & $0.10(0.01)$ \\
\hline S80 & $4.4(0.06)$ & $4.7(0.02)$ & $0.06(0.006)$ & $0.04(0.001)$ & $0.57(0.01)$ & $0.55(0.01)$ & $0.09(0.01)$ & $0.07(0.01)$ \\
\hline
\end{tabular}

Table 2. $P$-value results of an ANOVA on organic carbon, $\mathrm{pH}$, total nitrogen and phosphorus and yield (significant differences, i.e., $p \leq 0.05$ are in bold).

\begin{tabular}{cccccc}
\hline & $\mathbf{p H}$ & Total P & Org. C & Total N & Yield \\
\hline Rainforest & & & & & \\
Treatments & $\mathbf{0 . 0 0 2}$ & 0.208 & 0.432 & 0.105 & $\mathbf{0 . 0 1 8}$ \\
Time & 0.243 & 0.533 & 0.212 & 0.487 & \\
Treatments*Time & $\mathbf{0 . 0 1 2}$ & 0.098 & 0.327 & 0.299 & \\
\hline Dry Savanna & & & & & 0.005 \\
Treatments & $\mathbf{0 . 0 0 2}$ & 0.607 & $\mathbf{0 . 0 0 6}$ & 0.607 & 0.816 \\
$\quad$ Time & $\mathbf{0 . 0 0 6}$ & 0.816 & 0.996 & 0.394 & \\
Treatments*Time & $\mathbf{0 . 0 0 3}$ & 0.394 & 0.538 & & \\
\hline
\end{tabular}

\subsection{GHG Emissions}

Daily $\mathrm{N}_{2} \mathrm{O}$ emissions ranged from 0.012 to $13.58 \mathrm{mg} \mathrm{N} / \mathrm{kg} /$ day in the $D S$ (Figure $3 \mathrm{a}$ ), and in the $R F$, ranged from $0.27 \mathrm{mg}$ to $33.80 \mathrm{~N} / \mathrm{kg}$ /day (Figure $3 \mathrm{~b}$ ). In both ecoregions, daily $\mathrm{N}_{2} \mathrm{O}$ emissions were higher in treatments that received urea and manure+urea than in the controls, $\mathrm{C}$ or manure treatment which had the lowest emissions in both ecoregions (Figure $3 a, b)$. When we averaged the total emissions of each treatment by ecoregion over the 21 days, in the $D S$, the treatment that received manure $\left(0.24 \mathrm{mg} \mathrm{N} / \mathrm{kg} /\right.$ day), had a lower daily $\mathrm{N}_{2} \mathrm{O}$ emission than the manure + urea, M80, treatment (2.24 mg N/kg/day) which was nine times as much as the manure treatment emissions, while the urea treatment, O80 (2.04 mg N/kg/day) was more than eight times the emissions of the manure alone (Figure A1a). In the $R F$, the manure + urea, M80, treatment (5.71 mg N/kg/day) had a lower $\mathrm{N}_{2} \mathrm{O}$ emissions than the urea treatment, $\mathrm{O} 80,(7.54 \mathrm{mg} \mathrm{N} / \mathrm{kg} /$ day $)$, and nearly tripled the emissions from the control, C, (2.64 mg N/kg/day). However, the difference in the daily $\mathrm{N}_{2} \mathrm{O}$ emissions between the M80 and $\mathrm{O} 80$ was not statistically significant (Figure A1a). $\mathrm{N}_{2} \mathrm{O}$ emissions in both ecoregions was lowest in the $\mathrm{C}$ and $\mathrm{M}$ treatments, (Figure A1a,b).

Daily $\mathrm{CO}_{2}$ emissions ranged from 6.59 to $48.62 \mathrm{~g} \mathrm{C} / \mathrm{kg} /$ day in the $D S$, (Figure 3c), compared to the $R F$, which ranged from 11.23 to $37.10 \mathrm{~g} \mathrm{C} / \mathrm{kg} /$ day (Figure $3 \mathrm{~d}$ ). When we averaged the total emissions of each treatment by ecoregion over the 21 days, in the $R F$ soils, $\mathrm{CO}_{2}$ emissions increased from $\mathrm{O} 80$ (20.94 g C/kg/day) < S80 (21.03 g C/kg/day) < M (21.88 g C/kg/day) < M80 (22.73 g C/kg/day) < C (22.98 $\mathrm{g} \mathrm{C} / \mathrm{kg} /$ day). In the $D S, \mathrm{CO}_{2}$ emissions followed the order M80 (26.63 g C/kg/day) < O80 (19.71 g $\mathrm{C} / \mathrm{kg} /$ day) < S80 (18.80 g C/kg/day) < M (16.54 g C/kg/day) < C (13.04 g C/kg/day) (Figure A1b).

Cumulative $\mathrm{N}_{2} \mathrm{O}$ emission ranged from 24.78 to $99.08 \mathrm{mg} \mathrm{N} / \mathrm{kg}$ soil in the DS (Figure 4a) (Figure 4b), and 64.53 to $279.54 \mathrm{mg} \mathrm{N} / \mathrm{kg}$ soil in the $R F$ and was higher in the $R F$ than in the $D S$. In the $R F$, cumulative 
$\mathrm{N}_{2} \mathrm{O}$ emission was highest in the urea treatment, $\mathrm{O} 80(279.54 \mathrm{mg} / \mathrm{kg}$ soil N$)$, followed by the manure + urea treatment, M80 (220.86 mg N/kg soil), the S80, $C$ and $M$ had 115.81, 81.94, and $60.53 \mathrm{mg} \mathrm{N} / \mathrm{kg}$ soil respectively (Figure $4 b)$. In the DS, $M 80\left(99.08 \mathrm{mg} \mathrm{N} / \mathrm{kg}\right.$ soil) had the highest cumulative $\mathrm{N}_{2} \mathrm{O}$ emission, followed by the urea treatment, O80 (87.39 $\mathrm{mg} \mathrm{N} / \mathrm{kg}$ soil), the S80, C and M had 65.89, 27.59, and $24.78 \mathrm{mg} \mathrm{N} / \mathrm{kg}$ soil respectively (Figure $4 \mathrm{a}$ ). In both ecoregions, the manure treatment had the least cumulative $\mathrm{N}_{2} \mathrm{O}$ emission and was even lower than the control (Figure $4 \mathrm{a}, \mathrm{b}$ ).
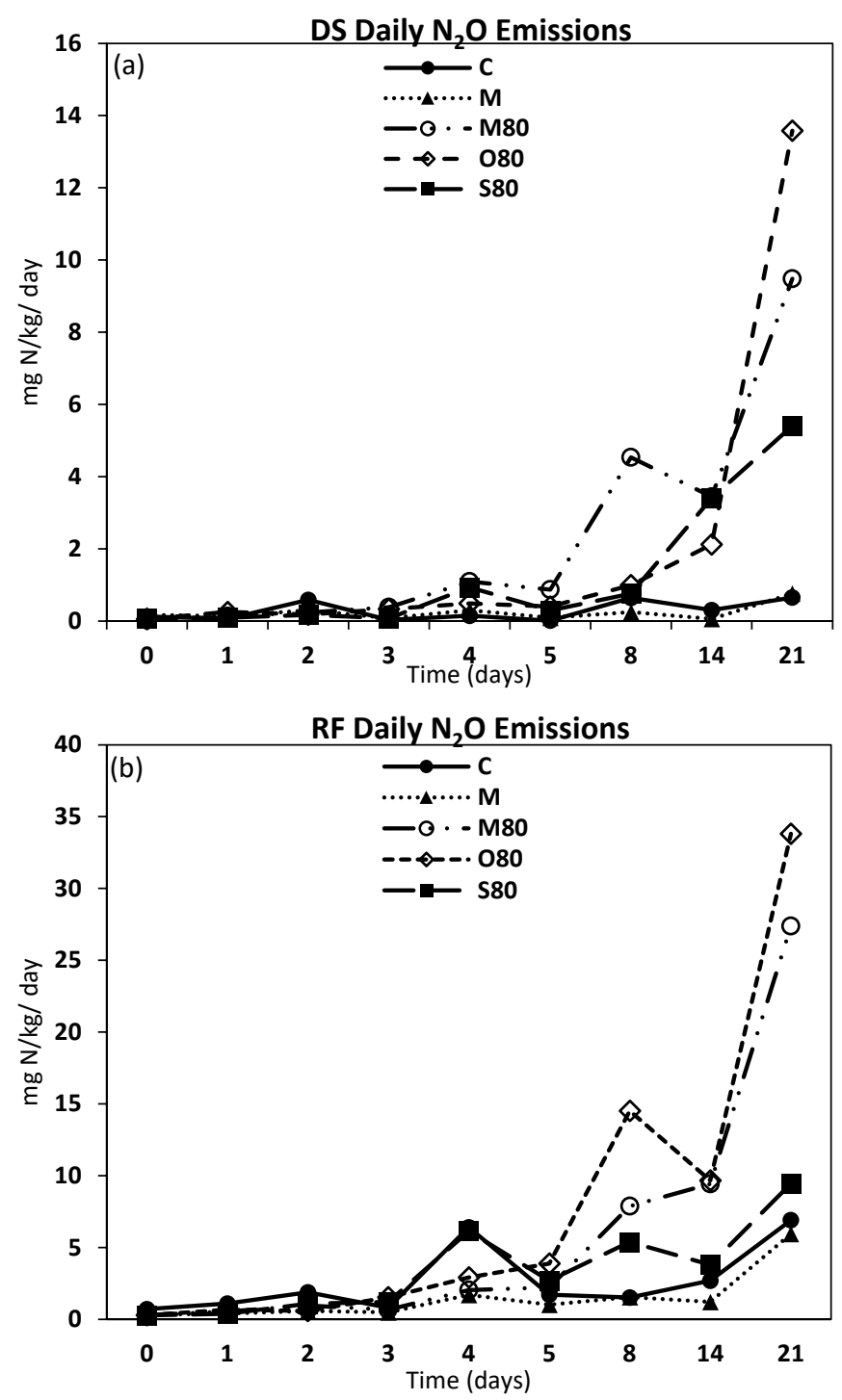

Figure 3. Cont. 

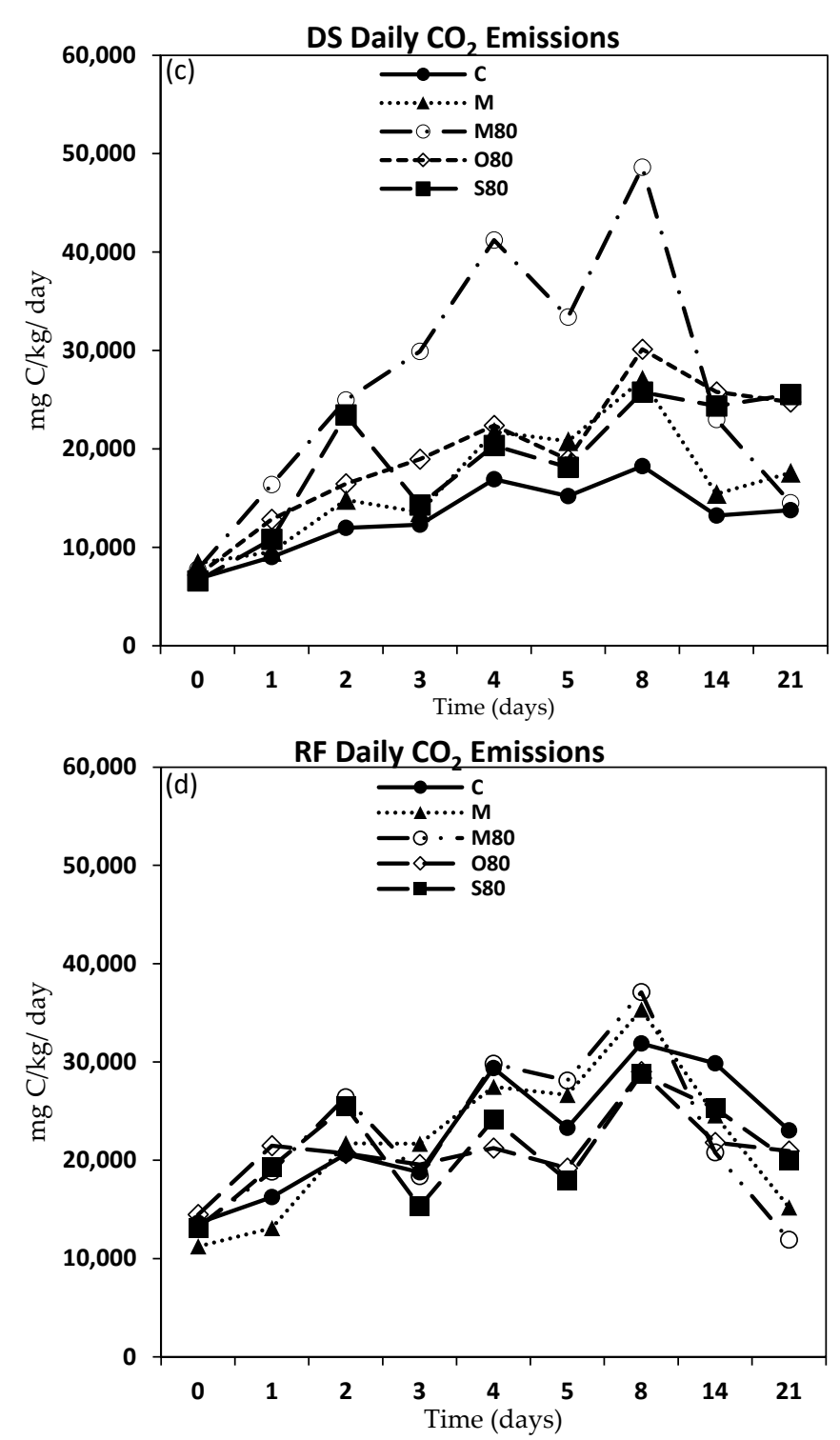

Figure 3. Mean $(n=3)$ daily emissions by treatments of $\mathrm{N}_{2} \mathrm{O}$ from the (a) Dry Savanna, $D S$ and (b) Rainforest, $R F$ soils and of $\mathrm{CO}_{2}$ from the (c) Dry Savanna, $D S$ and (d) Rainforest, $R F$ soils. $\mathrm{C}=$ control, $\mathrm{M}=$ manure treatment, $\mathrm{M} 80=$ Manure $+80 \mathrm{~kg} \mathrm{~N} / \mathrm{ha}, \mathrm{O} 80=$ No manure $+80 \mathrm{~kg} \mathrm{~N} / \mathrm{ha} \mathrm{S} 80=$ soil pot microdosed with $80 \mathrm{~kg} \mathrm{~N} /$ ha without any vegetables.

Cumulative $\mathrm{CO}_{2}$ emission ranged from 322.96 to $624.97 \mathrm{~g} \mathrm{C} / \mathrm{kg}$ soil in the $\mathrm{DS}$, and 497.06 to $579.47 \mathrm{~g} \mathrm{C} / \mathrm{kg}$ soil in the $R F$ (Figure $5 \mathrm{~b}$ ) (Figure $5 \mathrm{a}$ ). In the $R F$, cumulative emission was highest in the control, $C$ ( $579.47 \mathrm{~g} \mathrm{C} / \mathrm{kg}$ soil), followed by the manure, $\mathrm{M}(537.60 \mathrm{~g} \mathrm{C} / \mathrm{kg}$ soil), manure + urea, M80 (522.91 g C/kg soil), soil pot, $S 80$ (513.12 g C/ $\mathrm{kg}$ soil) and it was least in the urea treatment, O80 (497.06 g C/kg soil) (Figure 5b). In the $D S$, cumulative $\mathrm{CO}_{2}$ emission was highest in the manure + urea, M80 (624.97 g C/ $\mathrm{kg}$ soil), followed by the urea treatment, O80 (524.72 $\mathrm{g} \mathrm{C} / \mathrm{kg}$ soil), soil pot, S80 (494.88 g C/kg soil), the manure, M (411.61 g C/kg soil), and the control, C (322.96 g C/kg soil) which had the least cumulative (Figure $5 \mathrm{a}$ ) $\mathrm{CO}_{2}$ emission. 

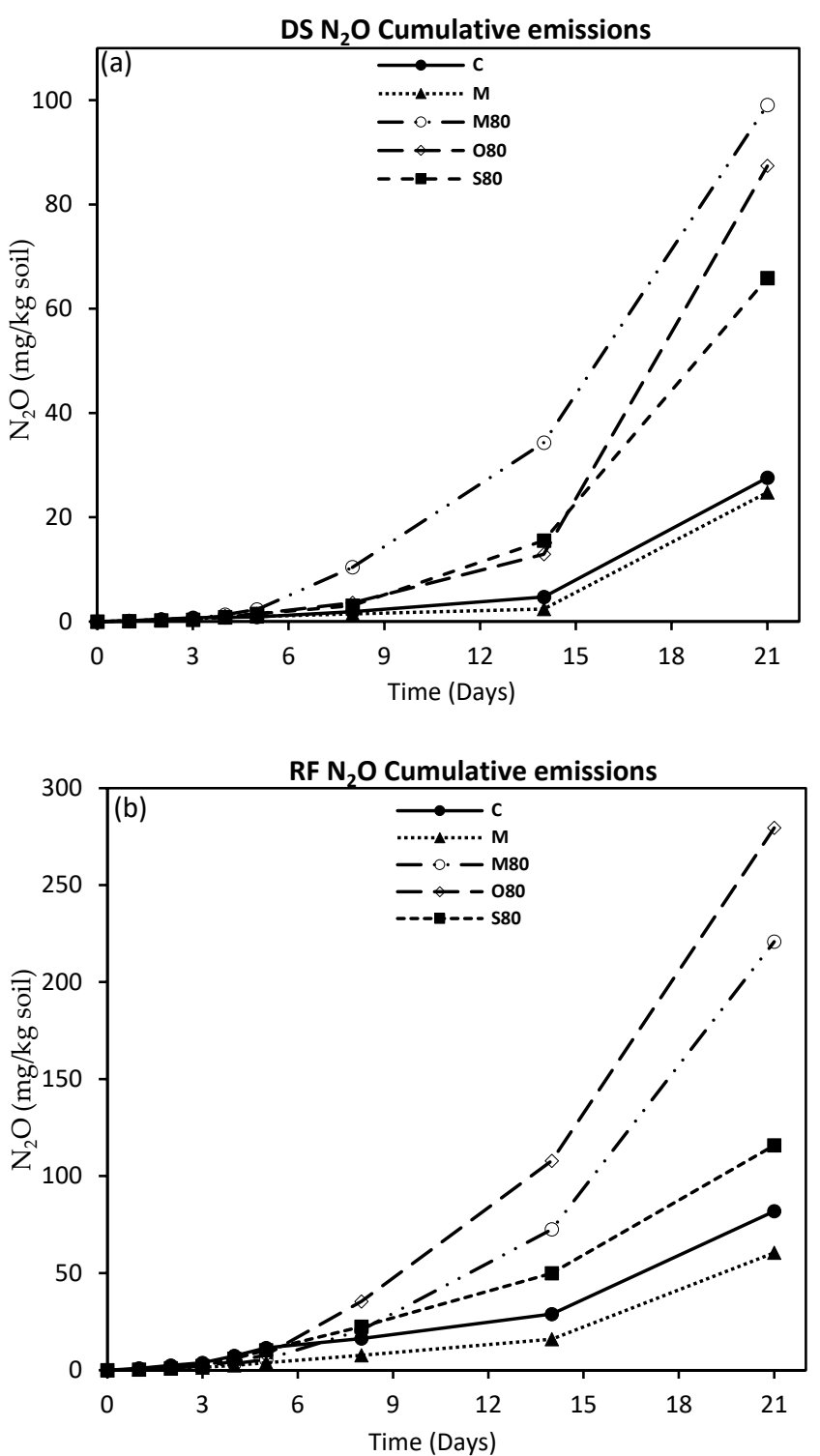

Figure 4. Cumulative $\mathrm{N}_{2} \mathrm{O}$ emissions from four cropping treatments on (a) Dry Savanna, $D S$, and (b) Rainforest, $R F$, soils. $C=$ control, $\mathrm{M}=$ manure treatment, $\mathrm{M} 80=$ Manure $+80 \mathrm{~kg} \mathrm{~N} / \mathrm{ha}, \mathrm{O} 80=\mathrm{No}$ manure $+80 \mathrm{~kg} \mathrm{~N} /$ ha S80 = soil pot microdosed with $80 \mathrm{~kg} \mathrm{~N} /$ ha without any vegetables. $(\mathrm{n}=3)$.

\subsection{ATR-FTIR Spectroscopy}

The relative abundance of different $C$ functional groups (Tables A1 and A2) was estimated using the relative intensities of the ATR-FTIR bands. While the FTIR bands did not show statistically significant differences amongst the fertilizer treatments, there were similar trends amongst the FTIR bands of related C functional groups. In the DS samples, the bands at 1430, 1540, 1600 and $1640 \mathrm{~cm}^{-1}$ had the highest relative absorbance in the manure+urea (M80) treatment, followed by the manure (M) treatment (Figure 6). In contrast, the bands at 1000, 1100 and $1160 \mathrm{~cm}^{-1}$ showed higher relative absorbance in urea treated samples (S80, O80 and M80) (Figure 6c). The absorbance band near $1640 \mathrm{~cm}^{-1}$ is attributed to $\mathrm{C}=\mathrm{O}$ stretching of carboxylates and conjugated ketones, as well as to aromatic $\mathrm{C}(\mathrm{C}=\mathrm{C})$ stretching $[24,34,35]$, while the band at $1430 \mathrm{~cm}^{-1}$ is assigned to aliphatic $(\mathrm{C}-\mathrm{H})$ bending of $\mathrm{CH}_{2}$ and $\mathrm{CH}_{3}$ groups [34,35]. The band around $1600 \mathrm{~cm}^{-1}$ is assigned to amide N-H bends and $\mathrm{C}=\mathrm{N}$ stretching of amides [34]. The absorbance band at $1540 \mathrm{~cm}^{-1}$ is assigned to aromatic $\mathrm{C}-\mathrm{H}$ and $\mathrm{C}=\mathrm{C}$ vibrations [36]. The bands at $1160-1000 \mathrm{~cm}^{-1}$ are assigned to $\mathrm{C}-\mathrm{O}-\mathrm{C}$ and $\mathrm{C}-\mathrm{OH}$ stretch of polysaccharides, polysaccharide-like compounds [35] or of other groups such as alcohols, ether and 
esters [37,38]. Thus, processed $C$ forms such as aromatic- $C$, aliphatic- $C$ and carboxylic- $C$ showed higher abundance in manure-treated samples ( $M$ and $M 80)$, while the polysaccharide-derived $C$ forms are of higher abundance in urea-treated samples (S80, O80 and M80) in the DS samples.
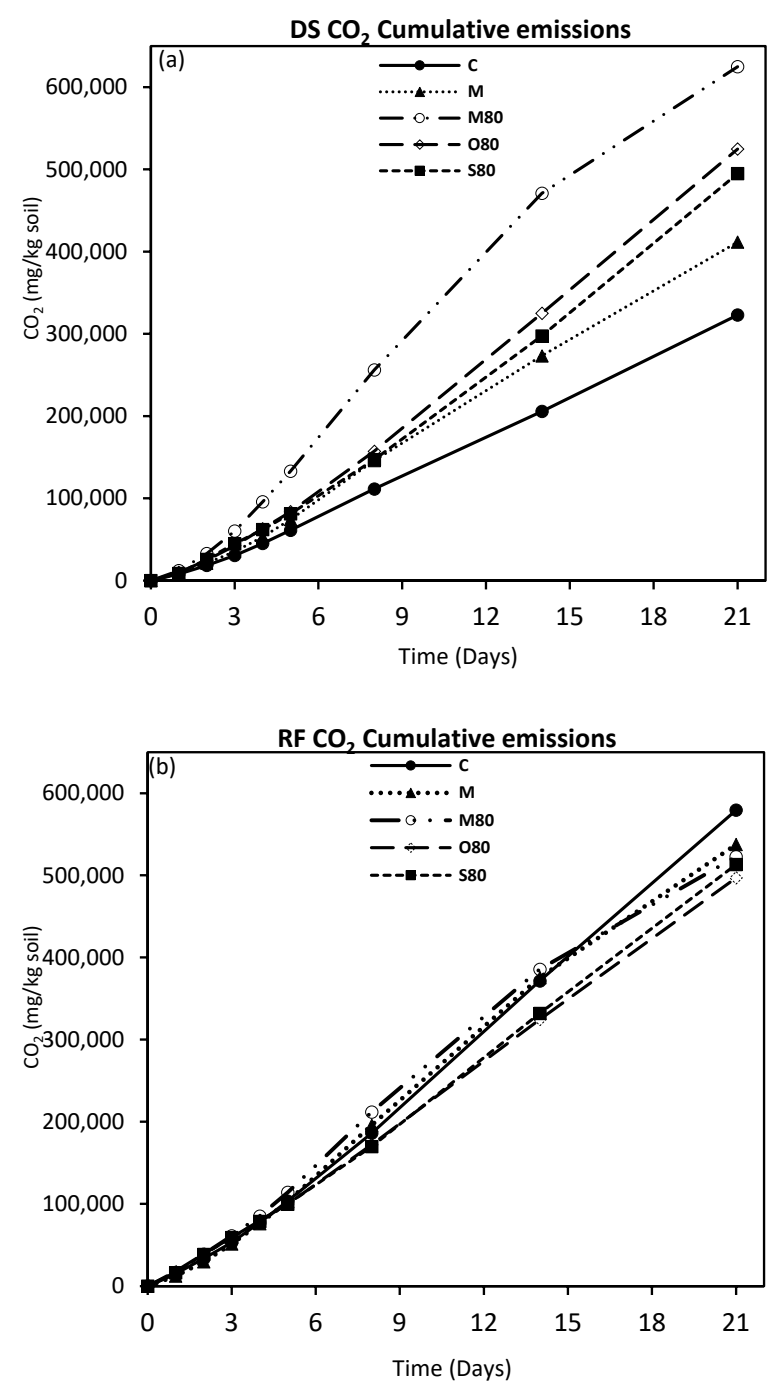

Figure 5. Cumulative $\mathrm{CO}_{2}$ emissions from four cropping treatments on (a) Dry Savanna, DS, and (b) Rainforest, $R F$, soils. $C=$ control, $\mathrm{M}=$ manure treatment, $\mathrm{M} 80=$ Manure $+80 \mathrm{~kg} \mathrm{~N} / \mathrm{ha}, \mathrm{O} 80=\mathrm{No}$ manure $+80 \mathrm{~kg} \mathrm{~N} /$ ha S $80=$ soil pot microdosed with $80 \mathrm{~kg} \mathrm{~N} /$ ha without any vegetables.

In the $R F$ samples, the $1640 \mathrm{~cm}^{-1}$ band had the highest relative absorbance in the control and the manure treatments, and followed by the urea treated samples (S80 and O80), with the M80 treatment having the least relative absorbance (Figure 7a). For the $1430 \mathrm{~cm}^{-1}$ band, the $S 80$ treatment had the highest relative absorbance, with the $\mathrm{C}$ and $\mathrm{M}$, and M80 and O80 having identical absorbance (Figure $7 \mathrm{~b}$ ). For the band at $1000 \mathrm{~cm}^{-1}$, the urea treated samples (S80 and O80) had the highest relative absorbance (Figure 7a), followed by the $\mathrm{C}$ and $\mathrm{M}$ treatments, which had similar relative absorbance, and the M80 treatment having the least relative absorbance. Unlike the $D S$ samples, the samples in $R F$ soils did not show repeatable trends between the fertilizer treatments. 

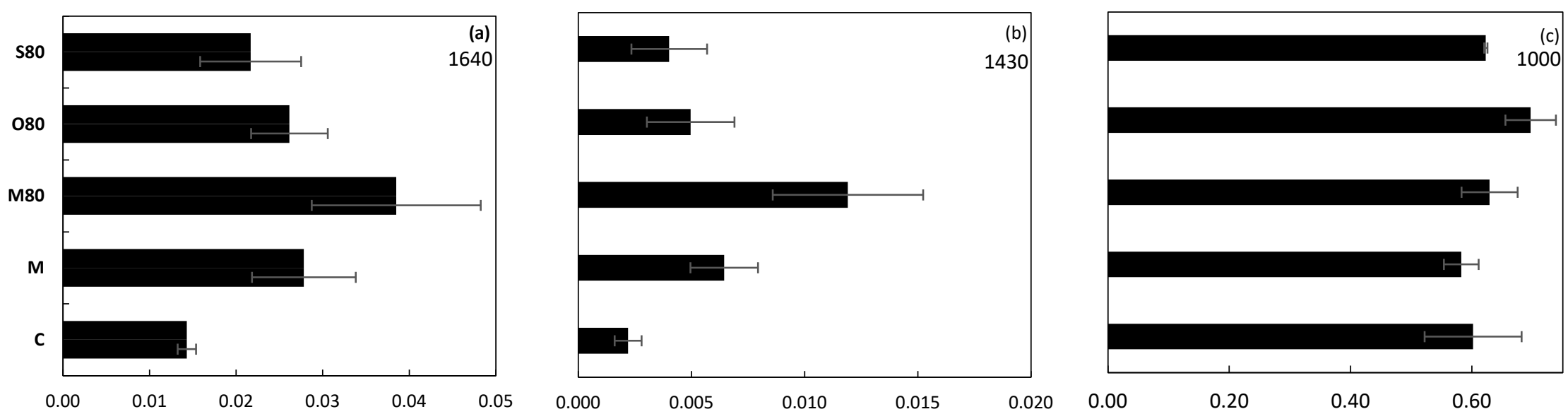

Figure 6. Mean $(\mathrm{n}=3)$ relative absorbance intensities of $(\mathbf{a}) 1640 \mathrm{~cm}^{-1}$ (b) $1430 \mathrm{~cm}^{-1}$ and (c) $1000 \mathrm{~cm}^{-1}$ ATR-FTIR bands identified for dry savanna soils after harvest. $\mathrm{C}=$ control, $\mathrm{M}=$ manure treatment, $\mathrm{M} 80=$ Manure $+80 \mathrm{~kg} \mathrm{~N} / \mathrm{ha}, \mathrm{O} 80=$ No manure $+80 \mathrm{~kg} \mathrm{~N} / \mathrm{ha} 580=$ soil pot with $80 \mathrm{~kg} \mathrm{~N} / \mathrm{ha}$ without any vegetables.
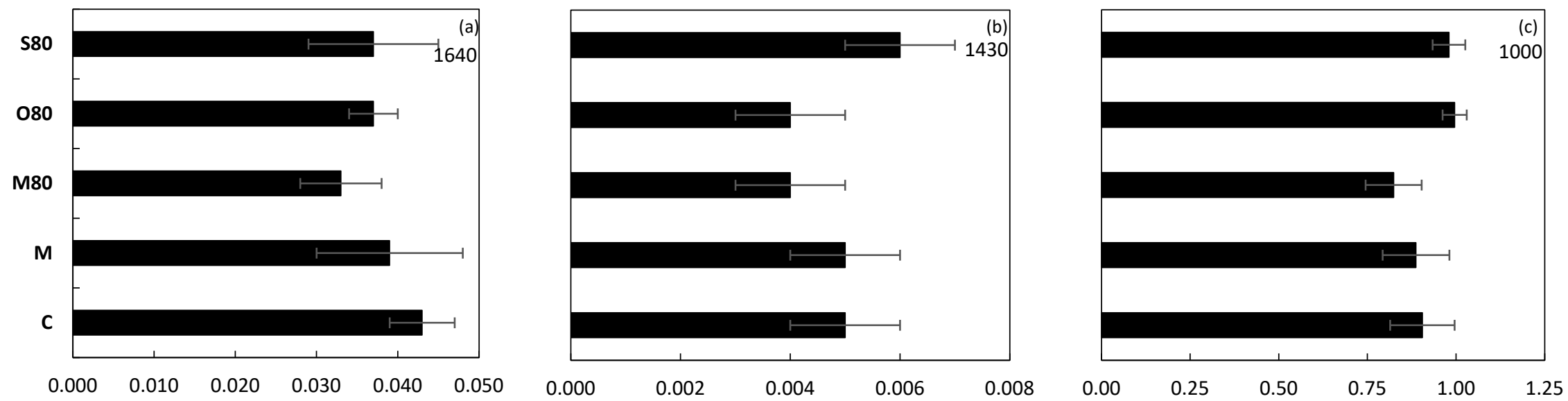

Figure 7. Mean $(\mathrm{n}=3)$ relative absorbance intensities of $(\mathbf{a}) 1640 \mathrm{~cm}^{-1}(\mathbf{b}) 1430 \mathrm{~cm}^{-1}$ and (c) $1000 \mathrm{~cm}^{-1}$ ATR-FTIR bands identified for rainforest soils after harvest. $\mathrm{C}=$ control, $\mathrm{M}=$ manure treatment, $\mathrm{M} 80=$ Manure $+80 \mathrm{~kg} \mathrm{~N} / \mathrm{ha}, \mathrm{O} 80=$ No manure $+80 \mathrm{~kg} \mathrm{~N} / \mathrm{ha} 580=$ soil pot with $80 \mathrm{~kg}$ N/ha without any vegetables. 
A correlation analysis found the bands at $1430,1540,1600$ and $1640 \mathrm{~cm}^{-1}$ to be positively correlated with soil $\mathrm{pH}$ in the $D S$. While in the $R F$, there was a negative correlation between the bands and total $\mathrm{N}$. There was also a negative correlation between the $1000 \mathrm{~cm}^{-1}$ band with SOC in both the DS and RF (Table 3).

Table 3. Pearson correlation coefficients between the relative intensity of absorbance of ATR-FTIR bands, soil pH and nutrient concentrations for Dry Savanna and Rainforest soils. ${ }^{* *}$, correlation is significant at the 0.01 level (2-tailed). *, correlation is significant at the 0.05 level (2-tailed).

\begin{tabular}{|c|c|c|c|c|c|c|c|}
\hline & B1000 & B1100 & B1160 & B1430 & B1540 & B1600 & B1640 \\
\hline \multicolumn{8}{|c|}{ Dry Savanna } \\
\hline $\mathrm{pH}$ & -0.111 & -0.418 & -0.359 & 0.597 * & $0.644 * *$ & $0.613 *$ & 0.516 * \\
\hline Total P & 0.003 & 0.035 & 0.011 & -0.044 & -0.038 & -0.074 & 0.016 \\
\hline Org C & $-0.558 *$ & 0.114 & 0.146 & -0.092 & 0.092 & 0.051 & 0.010 \\
\hline Total N & 0.225 & -0.193 & -0.300 & 0.008 & -0.123 & -0.068 & -0.125 \\
\hline \multicolumn{8}{|l|}{ Rainforest } \\
\hline $\mathrm{pH}$ & 0.067 & -0.407 & -0.419 & -0.125 & -0.267 & $-0.543 *$ & -0.289 \\
\hline Total P & -0.059 & 0.019 & -0.045 & 0.259 & -0.053 & 0.063 & 0.183 \\
\hline Org C & -0.534 * & 0.340 & 0.389 & $-0.541 *$ & -0.445 & -0.264 & $-0.577^{*}$ \\
\hline Total N & -0.227 & 0.051 & 0.062 & -0.528 * & -0.620 * & $-0.625 *$ & -0.556 * \\
\hline
\end{tabular}

\section{Discussion}

\subsection{Soil $\mathrm{pH}$ and Vegetable Yield}

The lower $\mathrm{pH}$ of $R F$ soils (Figure 2a,b) may be related to that soil having a higher Fe- or Al-related clay content than the $D S$ soils [27,39], while the decrease in $\mathrm{pH}$ observed in soils of the $D S$ after harvest (Table 1) may be caused by rhizosphere acidification due to organic acids or root exudates released by the vegetable. The significantly better vegetable yield measured in the RF soils over the DS (Figure 2a; Table 2) may also be attributed to the RF soils being able to retain nutrients better than the $D S$ soils due to their higher clay content [39], and the higher inherent organic C, N and P nutrient levels of the $R F$ soils than the DS soils (Table 1 ).

The yield response observed in all treatments receiving $\mathrm{N}$, either in the form of manure and/or urea in both ecoregions (Figure 2a) strongly suggests that $\mathrm{N}$ is limiting in these soils. We also found that vegetables will respond to any form of $\mathrm{N}$ addition, and the magnitude of the yield response will be influenced by the bioavailability of $\mathrm{N}$ and potential soil retention (as determined by soil organic matter content and soil structural properties). The urea treatment, O80 which marginally (but not significantly) out yielded the manure+urea treatment M80, and manure treatment M, in soils of both ecoregions (Figure 2a) provides strong evidence for this. These yield findings further continue the discussion on what the best fertility management practice might be for SSA crops. For example, Mando et al. (2005) [40] reported that manure addition led to greater sorghum yield than urea addition in the Sudano-Sahel region, Tovihoudji et al. (2017) [41] reported that maize yield increases in Northern Benin were greater for the urea treatment, and followed by manure compared to the unfertilized control, while Detchinli and Sogbedji (2015) [42] recommended a combination of mineral fertilizer and farm yard manure to sustain enhanced maize crop productivity and profitability. In this study, urea fertilization had no significant vegetable yield advantage over the combined use of manure and urea, and manure alone. Thus, our results suggest that vegetable response to mineral and/or organic fertilization may be more site (ecoregion) specific.

\subsection{GHG Emissions}

Average daily $\mathrm{N}_{2} \mathrm{O}$ emissions increased in response to urea and/or manure addition in soils of both ecoregions (Figure A1a). In the $D S$ soils, average daily $\mathrm{N}_{2} \mathrm{O}$ emissions (Figure A1a) and cumulative $\mathrm{N}_{2} \mathrm{O}$ emissions (Figure $4 \mathrm{~b}$ ) were lowest in the manure treatment and when manure was used in 
combination with urea, it increased the average daily $\mathrm{N}_{2} \mathrm{O}$ emissions in these soils (Figure A1a), and the cumulative $\mathrm{N}_{2} \mathrm{O}$ emissions, which was highest in the manure+urea treatment M80 (Figure $4 \mathrm{~b}$ ) of the DS samples. This suggests that the combined use of manure and urea slightly amplified cumulative $\mathrm{N}_{2} \mathrm{O}$ emissions in the $D S$ samples. We know that $\mathrm{N}_{2} \mathrm{O}$ emissions are significantly influenced by interactions with other factors such as clay content and soil structure [43,44], As such, it is possible that the low SOC (Table 1) and poor structural properties of the DS soils [27,39] provided minimal protection for the $\mathrm{N}$ content in the soil, including the manure, and resulted in high $\mathrm{N}$ losses. It is also possible that these soils have a threshold of $\mathrm{N}$ they can retain, and once $\mathrm{N}$ applied exceeds soil-holding capacity, $\mathrm{N}$ losses increases, as found by Malhi et al. (2006) [45] where $\mathrm{N}_{2} \mathrm{O}$ emissions increased when fertilized $\mathrm{N}$ levels exceeded $80 \mathrm{~kg} \mathrm{~N}^{-1}$, or by Kachanoski et al. (2003) [46] which reported increases in soil $\mathrm{N}_{2} \mathrm{O}$ emissions at $\mathrm{N}$ levels above $100 \mathrm{~kg} \mathrm{~N} \mathrm{ha}^{-1}$. If this is the case, incorporating plant residue and practicing minimal or no tillage may help improve the soils ability to retain more $\mathrm{N}$ [45].

The combined application of manure+urea suppressed average daily $\mathrm{N}_{2} \mathrm{O}$ emissions in the $R F$ soils when compared to emissions from the urea fertilization alone (Figure A1a), the cumulative $\mathrm{N}_{2} \mathrm{O}$ emission was highest in the urea treatment and lowest in the manure treatment (Figure 4a), with the combined use of manure and urea slightly suppressing cumulative $\mathrm{N}_{2} \mathrm{O}$ emissions when compared to emissions from urea fertilization alone. This is consistent with other $\mathrm{N}_{2} \mathrm{O}$ emissions studies from SSA such as Nyamadzawo et al. (2017) [9] in soils from Zimbabwe with very low $\mathrm{N}$ content cultivated with maize and wheat, which had lower $\mathrm{N}_{2} \mathrm{O}$ emissions in plots amended with a combination of inorganic $\mathrm{N}$ and manure and manure alone compared to soils amended with inorganic N. Dick et al. (2008) [13] also reported that combining organic manure and urea emitted significantly less $\mathrm{N}_{2} \mathrm{O}$ in soils of Mali cultivated in a cereal-legume rotation than urea alone. Vallejo et al. (2005) [47] in a study conducted on low organic $\mathrm{C}$ agricultural soil in Spain also reported that the application of organic fertilizers reduced emissions of $\mathrm{N}_{2} \mathrm{O}$, when compared to emissions from soils only treated with urea.

The lower cumulative $\mathrm{N}_{2} \mathrm{O}$ emissions in soils amended with manure can be attributed to $\mathrm{N}$ immobilization and slow release of mineral $\mathrm{N}$ [48]. It could also be that the addition of manure, a low soil C input favors complete denitrification to $\mathrm{N}_{2}$ and therefore reduces $\mathrm{N}_{2} \mathrm{O}$ emissions, or that the simultaneous addition of easily available $\mathrm{C}$ and $\mathrm{N}$ to an already deficient soil was more efficiently immobilized by the existing microbial biomass than when $\mathrm{N}$ alone was applied. Also, the application of manure, a low soil C input, implies a reduced energy source for microbial processes such as denitrification, while the low soil $\mathrm{N}$ means there is low substrate to drive both nitrification and denitrification which are responsible for the production of $\mathrm{N}_{2} \mathrm{O}$ [49]. Peng et al. (2011) [50] suggested that $\mathrm{N}_{2} \mathrm{O}$ emitting pathways compete for $\mathrm{N}$ with assimilatory $\mathrm{N}$ immobilization by both microbes and plants, and that it is only when $\mathrm{N}$ applied to soil exceeds microbial immobilization and plant $\mathrm{N}$ demand that $\mathrm{N}_{2} \mathrm{O}$ emissions increase. We propose that, in this study, additional $\mathrm{N}$ was likely taken up by the vegetable, leaving low amounts of $\mathrm{N}$ available for microbial use and loss as $\mathrm{N}_{2} \mathrm{O}$.

In the $D S$ soils, there was no significant difference between the average daily $\mathrm{CO}_{2}$ emissions of $\mathrm{C}$, $\mathrm{M}$ and M80, and the urea treatment, $\mathrm{O} 80$, suppressed daily $\mathrm{CO}_{2}$ emissions in these soils (Figure $\mathrm{A} 1 \mathrm{~b}$ ), but the manure+urea treatment, $\mathrm{M} 80$, amplified the emission of $\mathrm{CO}_{2}$, having a higher cumulative $\mathrm{CO}_{2}$ emission than the urea treatment, $\mathrm{O} 80$, and manure treatment, $\mathrm{M}$ (Figure $5 \mathrm{~b}$ ). This suggests that the combination of manure and urea in soils of this ecoregion increases $\mathrm{CO}_{2}$ emissions under current vegetable production system. This increment in the cumulative $\mathrm{CO}_{2}$ emissions in the manure+urea treatment may be linked to increase in the rate of decomposition and/or microbial metabolism, and is also linked to the manure+urea treatment, M80, having the highest rate of cumulative $\mathrm{N}_{2} \mathrm{O}$ emission (Figure $4 \mathrm{~b}$ ) as additional $\mathrm{N}$ from the manure further lowers the $\mathrm{C}: \mathrm{N}$ ratio and drives decomposition forward [13], or could also be as a result of the stimulation of the activity of heterotrophic microbes caused during the hydrolysis of urea [17] thereby producing more $\mathrm{CO}_{2}$. In the $R F$ soils, although not statistically significant, daily $\mathrm{CO}_{2}$ emissions were lowest in the urea treatment than they were in the manure+urea treatment, manure treatment and control (Figure $3 b$ ) this suggests that any form of $\mathrm{N}$ addition to soils of this ecoregion may lead to a decrease in $\mathrm{CO}_{2}$ emissions, and that the magnitude 
of the decrease is highest for mineral fertilization than for manure fertilization possibly because the addition of manure is likely introducing microbes to the soil, hence increasing $\mathrm{CO}_{2}$ emissions via microbial respiration.

\subsection{Treatment Effect on SOC Composition}

ATR-FTIR absorbance bands in soils of both ecoregions showed identical peak positions, indicating similar molecular C composition of SOM in soils of both ecoregions. The lack of any significant main and/or treatment effects limits our ability for comparison to just the observed trends.

The highest relative abundance of 1640 and $1430 \mathrm{~cm}^{-1}$ bands in the manure+urea, M80, treatment of the DS samples (Figure 6a,b) suggests that the combined use of manure and urea is increasing the proportion of the processed $C$ species including aliphatic- $C$, aromatic- $C$ and carboxylic- $C$ forms in the $D S$ samples. This observation is also supported by the lower abundance of the $1000 \mathrm{~cm}^{-1}$ band in the manure treatment and manure+urea treatment in the DS (Figure 6c) samples suggesting that the combined use of manure and urea leads to lower abundance of labile polysaccharide $C$ species due to their higher rate of decomposition in this treatment. This increased rate of decomposition observed in the $D S$ samples that received both manure and urea may be because the $D S$ samples are more $\mathrm{N}$ deficient than the $R F$ samples (Table 1), and as a result of the increased $\mathrm{N}$ input, microbial decomposition rate is increased. In the $R F$ samples however, we observed that the combined use of manure and urea had a lower relative absorbance at the $1640 \mathrm{~cm}^{-1}$ band (Figure 7c), and similar relative absorbance at the $1430 \mathrm{~cm}^{-1}$ band with the urea treatment, $\mathrm{O} 80$. This suggests that the combined use of manure and urea did not increase the rate of microbial decomposition in the $R F$ samples.

\section{Conclusions}

Our analysis of the soils of both ecoregions showed that the combined use of manure and urea acted differently in the $R F$ and $D S$ soils in terms of regulating microbial activity, C speciation and GHG emissions. We found that the combined use of manure and urea increased the rate of decomposition in the DS samples, thus, increasing the proportion of the processed $\mathrm{C}$ species including aliphatic-C, aromatic-C and carboxylic-C forms in the DS samples, while no such effect on decomposition was observed in the $R F$ samples. We also found that the combined use of manure and urea led to an increase in cumulative $\mathrm{CO}_{2}$ and $\mathrm{N}_{2} \mathrm{O}$ emissions in the $D S$ soils, but suppressed both emissions in the $R F$ when compared to urea alone. These results agree with the trends shown in FTIR results, which showed higher abundance of processed $\mathrm{C}$ forms in the M80 treatment, thus indicating higher degree of microbial breakdown, which may be linked to higher cumulative $\mathrm{CO}_{2}$ and $\mathrm{N}_{2} \mathrm{O}$ emissions. The $R F$ soils do not show any such trends in FTIR bands indicating that addition of manure+urea affected microbial decomposition differently in $R F$ and $D S$ soil samples. Our results also show that the $R F$ soils had a higher vegetable yield than the $D S$ soils, with the urea, manure, and manure+urea treatment showing no significant difference in vegetable yield.

We found that by combining manure and urea, $R F$ farmers can reduce agricultural emissions without compromising productivity, dispelling any concerns that the combined use of manure and urea may result in relatively lower vegetable yields in the short-term. While we are not able to estimate the GHG footprint of urea production, combining urea with manure will have a positive impact on total GHG emissions without affecting yields. It is clear from this study that even the low organic matter sandy soils of SSA can be significant sources of $\mathrm{CO}_{2}$ and $\mathrm{N}_{2} \mathrm{O}$, and that fertility management to optimize yield, build/maintain soil productivity and mitigate greenhouse gas emission will differ by ecoregion, soil type and maybe even crop.

Author Contributions: D.O., P.B.I.A., O.A. and D.P. were responsible for the funding acquisition, project administration, provision of resources and technical information; A.O. and D.P. conceptualized the study; A.O. was responsible for the methodology and writing of the original manuscript; A.S. and G.D. helped with the gas and FTIR analysis respectively; G.D., A.S. and D.P. reviewed, edited and validated the manuscript. All authors have read and agreed to the published version of the manuscript. 
Funding: This research was funded by International Development Research Centre, IDRC, project number 107983, through the Canada International Food Security Research Fund (CIFSRF) of the Government of Canada through Foreign Affairs, Trade and Development Canada. The authors are extremely grateful.

Acknowledgments: The authors thank all technical support staff for their significant contributions throughout the research, particularly members of the Environmental Soil Chemistry research group and the Prairie Environmental Agronomy Research Laboratory at the University of Saskatchewan.

Conflicts of Interest: The authors declare no conflict of interest.

\section{Appendix A}

Table A1. The abundance of different $C$ functional groups in the soil samples before planting (BP) as estimated using the absorbance intensities of the ATR-FTIR bands.

\begin{tabular}{cccccccc}
\hline Band $\left(\mathbf{c m}^{-\mathbf{1}}\right)$ & $\mathbf{1 0 0 0}$ & $\mathbf{1 1 0 0}$ & $\mathbf{1 1 6 0}$ & $\mathbf{1 4 3 0}$ & $\mathbf{1 5 4 0}$ & $\mathbf{1 6 0 0}$ & $\mathbf{1 6 4 0}$ \\
\hline $\begin{array}{c}\text { Dry Savanna } \\
\text { C }\end{array}$ & & & & & & & \\
M & 1.023 & 0.811 & 0.249 & 0.007 & 0.020 & 0.036 & 0.034 \\
M80 & 0.803 & 1.312 & 0.463 & 0.007 & 0.012 & 0.036 & 0.030 \\
O80 & 0.889 & 0.535 & 0.118 & 0.008 & 0.020 & 0.032 & 0.043 \\
S80 & 0.877 & 0.578 & 0.157 & 0.008 & 0.021 & 0.041 & 0.055 \\
\hline Rainforest & & & & & & & \\
C & 0.708 & 0.737 & 0.266 & 0.005 & 0.007 & 0.020 & 0.021 \\
M & 0.689 & 0.719 & 0.245 & 0.003 & 0.006 & 0.017 & 0.017 \\
M80 & 0.784 & 0.961 & 0.366 & 0.002 & 0.009 & 0.024 & 0.020 \\
O80 & 1.156 & 0.558 & 0.202 & 0.001 & 0.004 & 0.008 & 0.012 \\
S80 & 0.000 & 1.406 & 0.475 & 0.004 & 0.009 & 0.030 & 0.025 \\
\hline
\end{tabular}

$\mathrm{C}=$ control, $\mathrm{M}=$ manure treatment, $\mathrm{M} 80=$ Manure $+80 \mathrm{~kg} \mathrm{~N} / \mathrm{ha}, \mathrm{O} 80=$ No manure $+80 \mathrm{~kg} \mathrm{~N} / \mathrm{ha}$ S80 = soil pot with $80 \mathrm{~kg}$ N/ha without any vegetables. C spectra for DS soils is excluded due to heavy noise interference.

Table A2. The abundance of different $\mathrm{C}$ functional groups in the soil sample after harvest (AH) as estimated using the absorbance intensities of the ATR-FTIR bands.

\begin{tabular}{cccccccc}
\hline Band $\left(\mathbf{c m}^{-\mathbf{1}}\right)$ & $\mathbf{1 0 0 0}$ & $\mathbf{1 1 0 0}$ & $\mathbf{1 1 6 0}$ & $\mathbf{1 4 3 0}$ & $\mathbf{1 5 4 0}$ & $\mathbf{1 6 0 0}$ & $\mathbf{1 6 4 0}$ \\
\hline Dry Savanna & & & & & & & \\
C & 0.602 & 0.716 & 0.265 & 0.002 & 0.006 & 0.019 & 0.014 \\
M & 0.582 & 0.667 & 0.278 & 0.006 & 0.013 & 0.033 & 0.028 \\
M80 & 0.629 & 0.738 & 0.288 & 0.012 & 0.017 & 0.046 & 0.038 \\
O80 & 0.697 & 1.058 & 0.375 & 0.005 & 0.011 & 0.031 & 0.026 \\
S80 & 0.623 & 1.016 & 0.369 & 0.004 & 0.008 & 0.022 & 0.022 \\
\hline Rainforest & & & & & & & \\
C & 0.905 & 1.069 & 0.364 & 0.005 & 0.020 & 0.039 & 0.043 \\
M & 0.887 & 0.837 & 0.233 & 0.005 & 0.016 & 0.029 & 0.039 \\
M80 & 0.824 & 0.772 & 0.252 & 0.004 & 0.014 & 0.030 & 0.033 \\
O80 & 0.996 & 0.692 & 0.231 & 0.004 & 0.017 & 0.031 & 0.037 \\
S80 & 0.980 & 0.633 & 0.194 & 0.006 & 0.018 & 0.029 & 0.037 \\
\hline
\end{tabular}

$\mathrm{C}=$ control, $\mathrm{M}=$ manure treatment, $\mathrm{M} 80=$ Manure $+80 \mathrm{~kg} \mathrm{~N} / \mathrm{ha}, \mathrm{O} 80=$ No manure $+80 \mathrm{~kg}$ N/ha S80 = soil pot with $80 \mathrm{~kg}$ N/ha without any vegetables. 

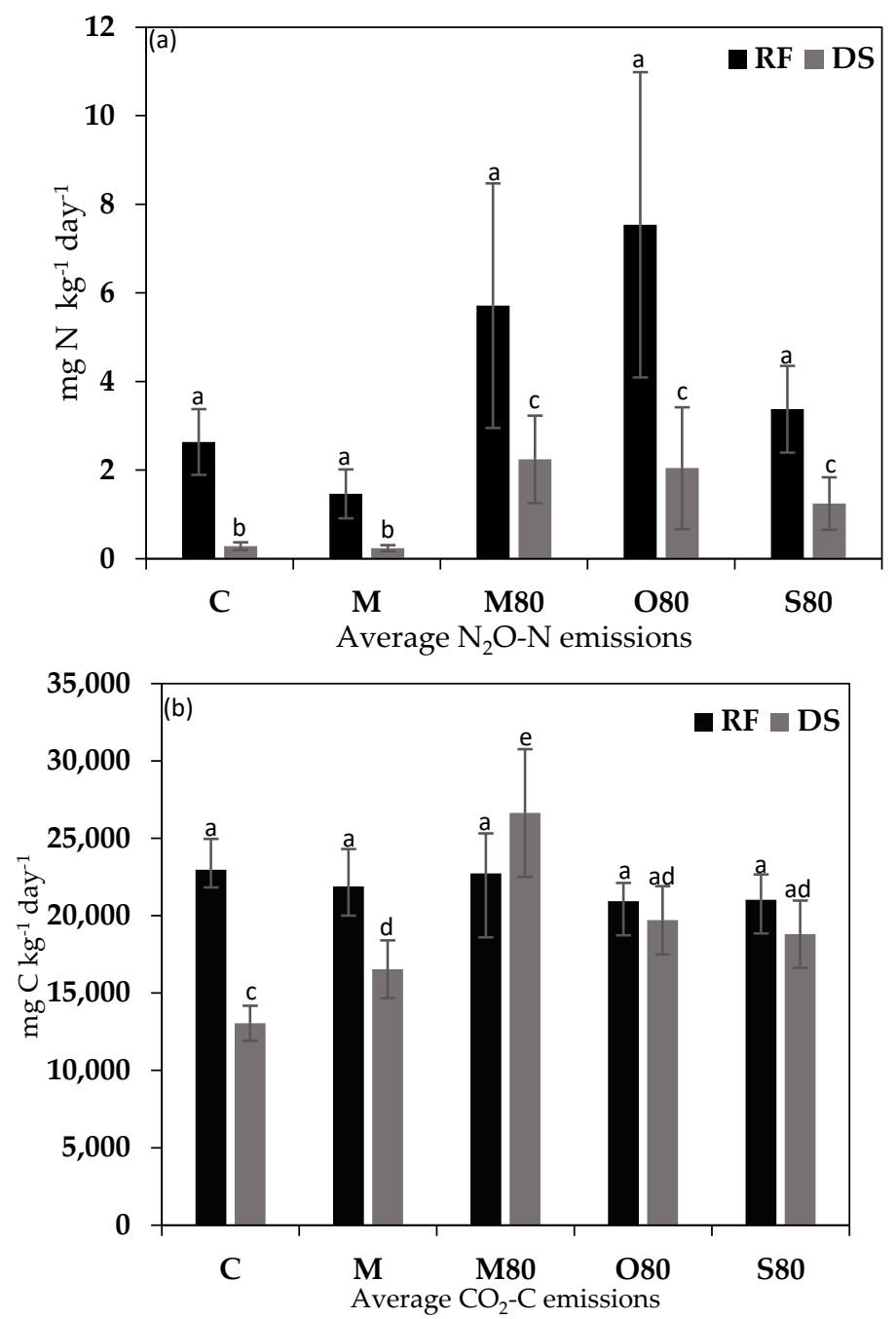

Figure A1. Mean ( $\mathrm{n}=3$ ) daily emissions of $(\mathbf{a}) \mathrm{N}_{2} \mathrm{O}$ and (b) $\mathrm{CO}_{2}$ from four cropping treatments on Rainforest, $R F$, and Dry Savanna, DS, soils averaged over the 21 days. $\mathrm{C}=$ control, $\mathrm{M}=$ manure only treatment, M80 = Manure $+80 \mathrm{~kg} \mathrm{~N} / \mathrm{ha}, \mathrm{O} 80=$ No manure $+80 \mathrm{~kg}$ N/ha S80 = soil pot microdosed with $80 \mathrm{~kg} \mathrm{~N} /$ ha without any vegetables.

\section{References}

1. Smith, P.; Martino, Z.; Cai, D. Agriculture. In Climate Change 2007: Mitigation; Metz, B., Davidson, O.R., Bosch, P.R., Dave, R., Meyer, L.A., Eds.; Contribution of Working Group III to the Fourth Assessment Report of the Intergovernmental Panel on Climate Change, Cambridge University Press: Cambridge, UK; New York, NY, USA, 2007.

2. Snyder, C.S.; Bruulsema, T.W.; Jensen, T.L.; Fixen, P.E. Review of greenhouse gas emissions from crop production systems and fertilizer management effects. Agric. Ecosyst. Environ. 2009, 133, 247-266. [CrossRef]

3. Blandford, D.; Hassapoyannes, K. The role of agriculture in global GHG mitigation. In OECD Food, Agriculture and Fisheries Papers; No. 112; OECD Publishing: Paris, France, 2018. [CrossRef]

4. Vitousek, P.M.; Naylor, R.; Crews, T.; David, M.B.; Drinkwater, L.E.; Holland, E.; Johnes, P.J.; Katzenberger, J.; Martinelli, L.A.; Matson, P.A.; et al. Nutrient imbalances in agricultural development. Science 2009, 324, 1519-1520. [CrossRef]

5. Bouwman, A.F.; Boumans, L.J.M.; Batjes, N.H. Emissions of $\mathrm{N}_{2} \mathrm{O}$ and $\mathrm{NO}$ from fertilized fields: Summary of available measurement data. Glob. Biogeochem. Cycl. 2002, 16, 6:1-6:13. [CrossRef]

6. Nziguheba, G.; Palm, C.A.; Berhe, T.; Denning, G.; Dicko, A.; Diouf, O.; Diru, W.; Flor, R.; Frimpong, F.; Harawa, R.; et al. The African green revolution: Results from the millennium villages project. In Advances in Agronomy; Academic Press: San Diego, CA, USA, 2010; Volume 109, pp. 75-115. 
7. Sanchez, P.A. Soil fertility and hunger in Africa. Science 2002, 295, 2019-2020. [CrossRef]

8. Alliance for a Green Revolution in Africa (AGRA). Building on the New Momentum in African Agriculture: AGRA in 2008; Alliance for a Green Revolution in Africa: Nairobi, Kenya, 2009.

9. Nyamadzawo, G.; Shi, Y.; Chirinda, N.; Olesen, J.E.; Mapanda, F.; Wuta, M.; Wu, W.; Meng, F.; Oelofse, M.; de Neergaard, A.; et al. Combining organic and inorganic nitrogen fertilisation reduces $\mathrm{N}_{2} \mathrm{O}$ emissions from cereal crops: A comparative analysis of China and Zimbabwe. Mitig. Adapt. Strateg. Glob. Chang. 2017, 22, 233-245. [CrossRef]

10. Mosier, A.; Kroeze, C.; Nevison, C.; Oenema, O.; Seitzinger, S.; van Cleemput, O. Closing the global atmospheric $\mathrm{N}_{2} \mathrm{O}$ budget: Nitrous oxide emissions through the agricultural nitrogen cycle. (OECD/IPCC/IEA Phase II Development of IPCC Guidelines for National Greenhouse Gas Inventories). In Dissipation of $N$ from the Human N-cycle, and Its Role in Present and Future $\mathrm{N}_{2} \mathrm{O}$ Emissions to the Atmosphere; Int. Workshop: Oslo, Norway, 1997; p. 4.

11. Ruser, R.; Flessa, H.; Russow, R.; Schmidt, G.; Buegger, F.; Munch, J.C. Emission of $\mathrm{N}_{2} \mathrm{O}, \mathrm{N}_{2}$ and $\mathrm{CO}_{2}$ from soil fertilized with nitrate: Effect of compaction, soil moisture and rewetting. Soil Biol. Biochem. 2006, 38, 263-274. [CrossRef]

12. Chirinda, N.; Carter, M.S.; Albert, K.R.; Ambus, P.; Olesen, J.E.; Porter, J.R.; Petersen, S.O. Emissions of nitrous oxide from arable organic and conventional cropping systems on two soil types. Agric. Ecosyst. Environ. 2010, 136, 199-208. [CrossRef]

13. Dick, J.; Kaya, B.; Soutoura, M.; Skiba, U.; Smith, R.; Niang, A.; Tabo, R. The contribution of agricultural practices to nitrous oxide emissions in semi-arid Mali. Soil Use Manag. 2008, 24, 292-301. [CrossRef]

14. Efthimiadou, A.; Bilalis, D.; Karkanis, A.; Froud-Williams, B. Combined organic/inorganic fertilization enhance soil quality and increased yield, photosynthesis and sustainability of sweet maize crop. Australian J. Crop. Sci. 2010, 4, 722.

15. Huang, Y.; Zou, J.; Zheng, X.; Wang, Y.; Xu, X. Nitrous oxide emissions as influenced by amendment of plant residues with different C:N ratios. Soil Biol. Biochem. 2004, 36, 973-981. [CrossRef]

16. Johnson, J.M.F.; Franzluebbers, A.J.; Weyers, S.L.; Reicosky, D.C. Agricultural opportunities to mitigate greenhouse gas emissions. Environ. Pollut. 2007, 150, 107-124. [CrossRef] [PubMed]

17. Serrano-Silva, N.; Luna-Guido, M.; Fernández-Luqueño, F.; Marsch, R.; Dendooven, L. Emission of greenhouse gases from an agricultural soil amended with urea: A laboratory study. Appl. Soil Ecol. 2011, 47, 92-97. [CrossRef]

18. Ramirez, K.S.; Craine, J.M.; Fierer, N. Consistent effects of nitrogen amendments on soil microbial communities and processes across biomes. Glob. Chang. Biol. 2012, 18, 1918-1927. [CrossRef]

19. Tan, H.; Barret, M.; Mooij, M.J.; Rice, O.; Morrissey, J.P.; Dobson, A.; Griffiths, B.; O'Gara, F. Long-term phosphorus fertilisation increased the diversity of the total bacterial community and the phoD phosphorus mineraliser group in pasture soils. Biol. Fertil. Soil. 2013, 49, 661-672. [CrossRef]

20. Fraser, T.; Lynch, D.H.; Entz, M.H.; Dunfield, K.E. Linking alkaline phosphatase activity with bacterial phoD gene abundance in soil from a long-term management trial. Geoderma 2015, 257, 115-122. [CrossRef]

21. Singh, S.N.; Verma, A. The potential of nitrification inhibitors to manage the pollution effect of nitrogen fertilizers in agricultural and other soils: A review. Environ. Pract. 2007, 9, 266. [CrossRef]

22. Artz, R.R.; Chapman, S.J.; Robertson, A.J.; Potts, J.M.; Laggoun-Défarge, F.; Gogo, S.; Comont, L.; Disnar, J.R.; Francez, A.J. FTIR spectroscopy can be used as a screening tool for organic matter quality in regenerating cutover peatlands. Soil Biol. Biochem. 2008, 40, 515-527. [CrossRef]

23. Lehmann, J.; Solomon, D. Organic carbon chemistry in soils observed by synchrotron-based spectroscopy. In Developments in Soil Science; Elsevier: Amsterdam, The Netherlands, 2010; Volume 34, pp. $289-312$.

24. Dhillon, G.S.; Gillespie, A.; Peak, D.; Van Rees, K.C. Spectroscopic investigation of soil organic matter composition for shelterbelt agroforestry systems. Geoderma 2017, 298, 1-13. [CrossRef]

25. Solomon, D.; Lehmann, J.; Kinyangi, J.; Liang, B.; Schäfer, T. Carbon K-edge NEXAFS and FTIR-ATR spectroscopic investigation of organic carbon speciation in soils. Soil Sci. Soc. Am. J. 2005, 69, 107-119. [CrossRef]

26. Solomon, D.; Lehmann, J.; Kinyangi, J.; Amelung, W.; Lobe, I.; Pell, A.; Riha, S.; Ngoze, S.; Verchot, L.; Mbugua, D. Long-term impacts of anthropogenic perturbations on dynamics and speciation of organic carbon in tropical forest and subtropical grassland ecosystems. Glob. Chang. Biol. 2007, 13, 511-530. [CrossRef] 
27. Jones, A.; Breuning-Madsen, H.; Brossard, M.; Dampha, A.; Deckers, J.; Dewitte, O.; Gallali, T.; Hallett, S.; Jones, R.; Kilasara, M.; et al. Zougmoré. In Soil Atlas of Africa; European Commission, Publications Office of the European Union: Luxembourg, France, 2013; p. 176.

28. Carter, M.R.; Gregorich, E.G. Soil Sampling and Methods of Analysis, 2nd ed.; CRC Press, Taylor \& Francis Group: Boca Raton, FL, USA, 2008.

29. Birch, H.F. The effect of soil drying on humus decomposition and nitrogen availability. Plant Soil 1958, 10, 9-31. [CrossRef]

30. Haberhauer, G.; Feigl, B.; Gerzabek, M.H.; Cerri, C. FT-IR spectroscopy of organic matter in tropical soils: Changes induced through deforestation. Appl. Spectrosc. 2000, 54, 221-224. [CrossRef]

31. Ellerbrock, R.H.; Gerke, H.H.; Bachmann, J.; Goebel, M.O. Composition of organic matter fractions for explaining wettability of three forest soils. Soil Sci. Soc. Am. J. 2005, 69, 57-66. [CrossRef]

32. Wojdyr, M. Fityk: A general-purpose peak fitting program. J. Appl. Crystallogr. 2010, 43, 1126-1128. [CrossRef]

33. Ellerbrock, R.H.; Höhn, A.; Gerke, H.H. Characterization of soil organic matter from a sandy soil in relation to management practice using FT-IR spectroscopy. Plant Soil 1999, 213, 55-61. [CrossRef]

34. Calderón, F.; Haddix, M.; Conant, R.; Magrini-Bair, K.; Paul, E. Diffuse-reflectance Fourier-transform mid-infrared spectroscopy as a method of characterizing changes in soil organic matter. Soil Sci. Soc. Am. J. 2013, 77, 1591-1600.

35. Parikh, S.J.; Goyne, K.W.; Margenot, A.J.; Mukome, F.N.; Calderón, F.J. Soil chemical insights provided through vibrational spectroscopy. In Advances in Agronomy; Academic Press: San Diego, CA, USA, 2014; Volume 126, pp. 1-148.

36. Bornemann, L.; Welp, G.; Amelung, W. Particulate organic matter at the field scale: Rapid acquisition using mid-infrared spectroscopy. Soil Sci. Soc. Am. J. 2010, 74, 1147-1156. [CrossRef]

37. Janik, L.J.; Merry, R.H.; Forrester, S.; Lanyon, D.; Rawson, A. Rapid prediction of soil water retention using mid infrared spectroscopy. Soil Sci. Soc. Am. J. 2007, 71, 507-514. [CrossRef]

38. Janik, L.J.; Skjemstad, J.; Shepherd, K.; Spouncer, L. The prediction of soil carbon fractions using mid-infrared-partial least square analysis. Aust. J. Soil Res. 2007, 45, 73-81. [CrossRef]

39. Olaleye, A.; Oyedele, D.; Akponikpe, P.; Kar, G.; Peak, D. Molecular Scale Studies of Phosphorus Speciation and Transformation in Manure Amended and Microdose Fertilized Indigenous Vegetable Production Systems of Nigeria and Republic of Benin. Soil Syst. 2020, 4, 5. [CrossRef]

40. Mando, A.; Bonzi, M.; Wopereis, M.C.S.; Lompo, F.; Stroosnijder, L. Long-term effects of mineral and organic fertilization on soil organic matter fractions and sorghum yield under Sudano-Sahelian conditions. Soil Use Manag. 2005, 21, 396-401. [CrossRef]

41. Tovihoudji, P.G.; Akponikpè, P.I.; Agbossou, E.K.; Bertin, P.; Bielders, C.L. Fertilizer microdosing enhances maize yields but may exacerbate nutrient mining in maize cropping systems in northern Benin. Field crop. Res. 2017, 213, 130-142. [CrossRef]

42. Detchinli, K.S.; Sogbedji, J.M. Yield performance and economic return of maize as affected by nutrient management strategies on ferralsols in coastal western Africa. Eur. Sci. J. 2015, 11, 27.

43. Potter, C.S.; Matson, P.A.; Vitousek, P.M.; Davidson, E.A. Process modeling of controls on nitrogen trace gas emissions from soils worldwide. J. Geophys. Res. Atmos. 1996, 101, 1361-1377. [CrossRef]

44. Rees, R.M.; Wuta, M.; Furley, P.A.; Li, C. Nitrous oxide fluxes from savanna (miombo) woodlands in Zimbabwe. J. Biogeogr. 2006, 33, 424-437. [CrossRef]

45. Malhi, S.S.; Lemke, R.; Wang, Z.H.; Chhabra, B.S. Tillage, nitrogen and crop residue effects on crop yield, nutrient uptake, soil quality, and greenhouse gas emissions. Soil Tillage Res. 2006, 90, 171-183. [CrossRef]

46. Kachanoski, R.G.; O'Halloran, I.; Rochette, P. Site-Specific Application of Fertilizer N for Reducing Greenhouse Gas Emissions; Climate Change Funding Initiative in Agriculture; Canadian Agri-Food Research Council: Ottawa, ON, Canada, 2003.

47. Vallejo, A.; García-Torres, L.; Díez, J.A.; Arce, A.; López-Fernández, S. Comparison of N losses $\left(\mathrm{NO}^{-3}, \mathrm{~N}_{2} \mathrm{O}\right.$, $\mathrm{NO})$ from surface applied, injected or amended (DCD) pig slurry of an irrigated soil in a Mediterranean climate. Plant Soil 2005, 272, 313-325. [CrossRef]

48. Mapanda, F.; Wuta, M.; Nyamangara, J.; Rees, R.M. Effects of organic and mineral fertilizer nitrogen on greenhouse gas emissions and plant-captured carbon under maize cropping in Zimbabwe. Plant Soil 2011, 343, 67-81. [CrossRef] 
49. Chapuis-Lardy, L.Y.D.I.E.; Wrage, N.; Metay, A.; Chotte, J.L.; Bernoux, M. Soils, a sink for $\mathrm{N}_{2} \mathrm{O}$ ? A review. Glob. Chang. Biol. 2007, 13,1-17. [CrossRef]

50. Peng, Q.; Qi, Y.; Dong, Y.; Xiao, S.; He, Y. Soil nitrous oxide emissions from a typical semiarid temperate steppe in inner Mongolia: Effects of mineral nitrogen fertilizer levels and forms. Plant Soil 2011, 342, 345-357. [CrossRef] 